OPEN ACCESS

Edited by:

Anke Huckriede,

University Medical Center Groningen,

Netherlands

Reviewed by:

Marc Paul Girard,

Université Paris Diderot, France

Sofia A. Casares,

Naval Medical Research Center,

United States

${ }^{*}$ Correspondence: Liang-Tzung Lin Itlin@tmu.edu.tw

Specialty section:

This article was submitted to

Vaccines and Molecular Therapeutics,

a section of the journal

Frontiers in Immunology

Received: 15 October 2020

Accepted: 23 December 2020

Published: 05 February 2021

Citation:

Liu C-H, Lu C-H, Wong SH and Lin L-T

(2021) Update on Antiviral

Strategies Against COVID-19:

Unmet Needs and Prospects.

Front. Immunol. 11:616595.

doi: 10.3389/fimmu.2020.616595

\section{Update on Antiviral Strategies Against COVID-19: Unmet Needs and Prospects}

\author{
Ching-Hsuan Liu ${ }^{1,2}$, Cheng-Hua Lu ${ }^{1}$, Shu Hui Wong ${ }^{3}$ and Liang-Tzung Lin ${ }^{1,4 *}$ \\ 1 Graduate Institute of Medical Sciences, College of Medicine, Taipei Medical University, Taipei, Taiwan, ${ }^{2}$ Department of \\ Microbiology \& Immunology, Dalhousie University, Halifax, NS, Canada, ${ }^{3}$ International Ph.D. Program in Medicine, College of \\ Medicine, Taipei Medical University, Taipei, Taiwan, ${ }^{4}$ Department of Microbiology and Immunology, School of Medicine, \\ College of Medicine, Taipei Medical University, Taipei, Taiwan
}

By December 2020, the COVID-19 pandemic had caused more than 74 million confirmed cases and 1.6 million related deaths around the world. However, only a few drugs have been approved in certain areas and for use in conditional patients, and the vaccine candidates were only recently approved or authorized for emergency use without being fully implemented worldwide, suggesting that we are yet to reach effective control of the current outbreak as its uninhibited transmission continues precariously. Over the past few months, several therapeutic candidates have been proven ineffective in large clinical trials, while some other agents exhibited promising preliminary results. Meanwhile, the investigation of SARS-CoV-2-specific antivirals is underway. Despite still being preclinical, these agents could be beneficial for the long-term control of COVID-19 and deserve more research focus. In this article, we update the current status of therapeutic candidates that have been examined for COVID-19 management, including the virustargeting inhibitors and host-targeting agents, with their antiviral efficacy in vitro, in vivo, and in clinical studies. Finally, we highlight the current challenges and future prospect of developing potent therapeutic agents against COVID-19.

Keywords: Severe Acute Respiratory Syndrome Coronavirus 2 (SARS-CoV-2), Coronavirus Disease 2019 (COVID-19), treatment, therapeutic, antiviral

\section{INTRODUCTION}

Coronavirus Disease 2019 (COVID-19), an infectious disease resulting from the Severe Acute Respiratory Syndrome Coronavirus 2 (SARS-CoV-2) infection, has ignited the current global pandemic since December of 2019 when it first emerged in Wuhan, China. Although there were several outbreaks of coronavirus throughout history, including the Severe Acute Respiratory Syndrome (SARS) during 2002-2003 in South East Asia and Middle East Respiratory Syndrome (MERS) in 2012 in Middle East and 2015 in Korea (1), none of them caused such a huge widespread burden to public health as the current one does. By December 2020, there were over 74 million confirmed cases and 1.6 million deaths globally (2), but only a few antivirals have been approved or authorized for emergency use to treat COVID-19 patients. 
Coronaviruses are a group of enveloped, positive-sense, single-stranded RNA viruses that infect a variety of mammal and avian animals including civets, bats, humans, chickens, etc. Unlike HCoV-229E, NL63, OC43, and HKU-1, which typically cause common cold with mild upper respiratory symptoms in humans, SARS-CoV, MERS-CoV and the latest SARS-CoV-2 are associated with more complicated and severe clinical signs and symptoms. In acute SARS-CoV-2 infection, individuals usually show mild symptoms such as cough and fever. After the initial 2-14 days of incubation period, most COVID-19 patients develop pneumonia with dyspnea and hypoxemia, which can progress into acute respiratory disease (3). The fatality rate varies in different regions, ranging from $0.9-9.1 \%$ in the most affected countries (4). SARS-CoV-2 is mainly transmitted through respiratory droplets and close contact from person to person (3). Asymptomatic (5) or presymptomatic (6) carriers can also spread the virus, causing a big challenge to the control of COVID-19. Consequently, antivirals and vaccine development become the major task for further control of the current outbreak.

\section{VIROLOGY}

The genome of coronaviruses ranges from 27 to $32 \mathrm{~Kb}$ and follows an invariant 5'-replicase-S-E-M-N-3' organization containing a large replicase gene and four structural genes, nucleocapsid $(\mathrm{N})$, glycoprotein spike $(\mathrm{S})$, membrane protein $(\mathrm{M})$, and envelope protein (E). Ribosomal frameshiftingdependent translation of the replicase gene ORF1a and ORF1b forms two coterminal polyproteins ppla and pplab, which undergo autoproteolytic cleavage to produce 16 non-structural proteins (nsp1-16), including viral proteases, RNA dependent RNA polymerase (RdRp), and other viral accessory proteins (1). It is evident that both SARS-CoV and SARS-CoV-2 utilize the human angiotensin-converting enzyme 2 (ACE2) type I membrane protein as a receptor for viral entry (7). Coronaviruses enter either through direct membrane fusion with the presence of Transmembrane Serine Protease 2 (TMPRSS2) on the cell surface or through clathrin-mediated endocytosis, which requires endosomal proteases to prime the viral particle for viral-endosomal membrane fusion (8). Recent studies also suggested that CD147 could serve as an alternative receptor in lung, kidney, and ACE2-deficient cells such as CD4+ and CD8+ T cells, and allow SARS-CoV-2 entry through the endocytosis route (9). In addition, neuropilin-1 (NRP1) has been reported as an entry factor that binds to the furin-cleaved S1 fragment and enhances SARS-CoV-2 infection in the respiratory and olfactory epithelium $(10,11)$. After entry, viral genome is released into the cytoplasm and translated to primary viral polyproteins ppla and pplab, which self-process via the nsp3 papain-like protease (PLpro) and nsp5 3C-like protease (3CLpro), or the so-called main protease (Mpro), into various mature viral proteins that form the replication complex and membrane-associated complex (8). The replication complex comprising viral RdRp (nsp12), helicase (nsp13), exoribonuclease (nsp14), and RNA methyltransferases (nsp14 and 16) then initiates viral replication and transcription, producing new full-length nucleocapsid-encapsidated viral RNA genome in the endoplasmic reticulum (ER) (8). The nucleocapsid core becomes enveloped through the ER-Golgi intermediate compartment, and the viral $S$ protein is lastly glycosylated and cleaved in the Golgi apparatus before mature progeny virions are released through exocytosis for the next round of viral life cycle (8) (Figure 1).

\section{ANTIVIRAL DEVELOPMENT}

Given the need to develop antivirals against coronaviruses, numerous drug candidates are being evaluated for their therapeutic effect in COVID-19. These include viral polymerase inhibitors, protease inhibitors, helicase inhibitors, and host targeting agents. This review focuses on drugs that either have predicted/in vitro/in vivo antiviral activities against SARS-CoV-2 or related coronaviruses, or are being investigated in COVID-19 clinical setting (Table 1). Of note, several drugs have been proven non-effective in randomized controlled trials, including the human immunodeficiency virus (HIV) protease inhibitors lopinavir/ritonavir (LPV/r) (50) and darunavir/ cobicistat (DRV/c) (31), and the anti-malarial agents chloroquine (CQ) and hydroxychloroquine (HCQ) (50, 41). Although many of these have been discontinued as monotherapeutic agents for COVID-19 treatment, agent such as $\mathrm{LPV} / \mathrm{r}$ is still being assessed in combination with other drugs.

\section{RdRp Inhibitors/Nucleotide Analogs Ribavirin}

Ribavirin is an FDA-approved broad-spectrum antiviral prodrug that inhibits viral replication in several proposed mechanisms (51). As a guanosine analog, its metabolite ribavirin monophosphate (R-MP) has been reported to competitively inhibit host cellular inosine monophosphate dehydrogenase (IMPDH), which results in GTP depletion and affects downstream cellular and viral functions. The triphosphate derivative (R-TP) inhibits viral RdRp or creates viral mutagenesis by substituting GTP, although the activities could vary among viruses. In vitro studies reported that the anti-SARS-CoV activity of ribavirin is weak in Vero cells $\left(\mathrm{EC}_{50}>1 \mathrm{mg} / \mathrm{ml}\right)(52,53)$ but appears better in human cell lines $\left(\mathrm{EC}_{50}<10 \mu \mathrm{g} / \mathrm{ml}\right)(54)$. However, the effect of ribavirin in SARS patients appeared inconclusive and possibly harmful due to its toxicity (55), and later mouse studies demonstrated that ribavirin did not increase the survival rate of infected mice $(56,57)$. Similarly, ribavirin could not inhibit MERS-CoV replication in vitro (58). As for SARS-CoV-2, high concentration of ribavirin was required to suppress the infection $\left(\mathrm{EC}_{50}=109.50 \mu \mathrm{M}, \mathrm{SI}>3.65\right)(12)$. These findings suggest that ribavirin as a monotherapy is insufficient to inhibit coronaviruses and that combinatorial therapies are required, such as with interferon (IFN)- $\alpha$ for hepatitis $C$ virus (HCV) (59), with LPV/r viral protease inhibitors for SARS-CoV (60), and with LPV/r and IFN- $\alpha$ for MERS-CoV (61). A trial 


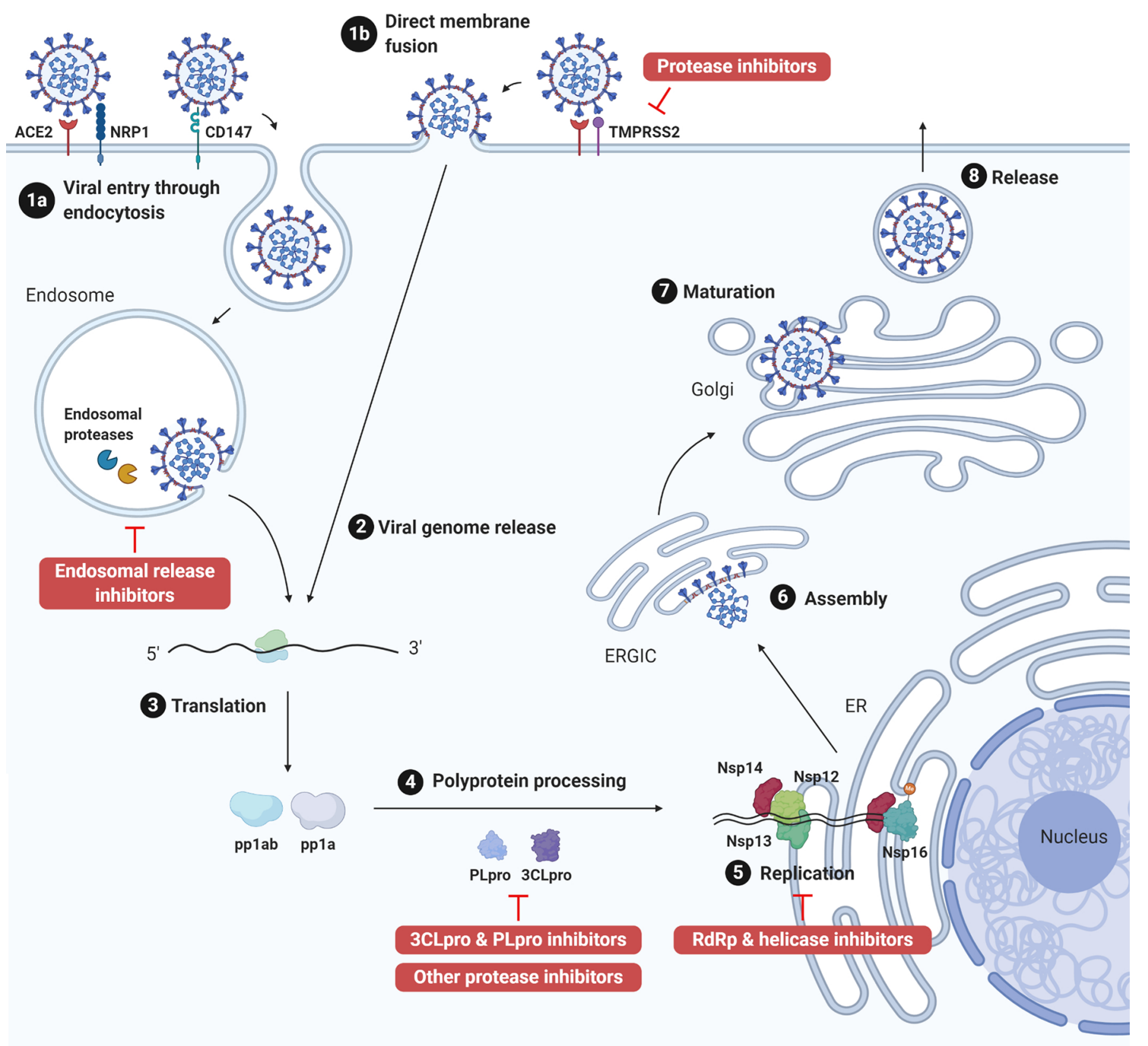

FIGURE 1 | SARS-CoV-2 life cycle and antiviral targets. SARS-CoV-2 infection initiates from viral binding to the host cell receptors angiotensin conversion enzyme 2 (ACE2) or CD147. The virus enters the cell either through endocytosis (1a), after which the virus is processed by endosomal proteases and fuses with endosomal membrane, or direct fusion with the plasma membrane in the presence of transmembrane protease serine 2 (TMPRSS2) (1b). Viral genome is released into the cytoplasm (2) and translated to polyprotein 1ab (pp1ab) and polyprotein 1a (pp1a) (3). Pp1a and pp1ab are further cleaved into 16 nonstructural proteins (nsp1-16) by the viral papain like protease (PLpro, nsp3) and 3C-like protease (3CLpro, nsp5) (4). Viral replication is initiated by replication complex (Nsp12-14) and RNA methyltransferase (nsp14, nsp16) in the endoplasmic reticulum (ER) (5). After which, new viral particles are assembled in the ER-Golgi intermediate compartment (ERGIC) (6) followed by spike protein glycosylation and maturation in the Golgi apparatus (7). Finally, progeny virions are released from the host cell through exocytosis (8). Created with Biorender.com.

evaluating the combination of ribavirin, $L P V / r$, and IFN- $\beta 1 b$ (NCT04276688) is described below.

\section{Favipiravir}

Favipiravir is a pyrazine-derived prodrug that is phosphoribosylated to its active form favipiravir-ribofuranosyl5'triphosphate (F-RTP), which incorporates into nascent viral RNA through competition with purine nucleotides and inhibits viral replication $(62,63)$. As a licensed antiviral for influenza in Japan and China, past studies have shown that favipiravir provides a broad-spectrum antiviral activity against multiple strains of influenza virus types A, B, and C (63-67) and a wide range of RNA viruses [reviewed in (68)] in vitro and in vivo.

Like ribavirin, high dose of favipiravir $\left(\mathrm{EC}_{50}=61.88\right.$ $\mu \mathrm{M}, \mathrm{SI}>6.46)$ was required to inhibit SARS-CoV-2 infection in vitro (12), and a recent preprint suggested that the drug only decreased $0.9 \log _{10}$ viral RNA copies/mg lung tissue in infected hamsters without affecting the pathology or preventing transmission (14). Nonetheless, favipiravir has been investigated in several clinical trials with preliminary results. In a non-randomized open-label before-after controlled trial (ChiCTR2000029600), patients who received favipiravir plus 
TABLE 1 | Therapeutic candidates for COVID-19.

\begin{tabular}{|c|c|c|c|c|}
\hline Class & Drug & \multicolumn{3}{|c|}{ Antiviral effect } \\
\hline \multirow[t]{4}{*}{$\begin{array}{l}\text { Polymerase } \\
\text { inhibitor }\end{array}$} & Ribavirin & $\begin{array}{l}\mathrm{EC}_{50}=109.50 \mu \mathrm{M}, \mathrm{CC}_{50}>400 \mu \mathrm{M}, \mathrm{SI}>3.65 ; \mathrm{MOI}= \\
0.05,48 \mathrm{hpi} \text {, Vero E6 (12) }\end{array}$ & $\mathrm{N} / \mathrm{A}$ & $\begin{array}{l}\text { IFN- } \beta 1 \text { b (subcutaneous), LPV/r, ribavirin: faster } \\
\text { viral clearance and reduced inflammatory } \\
\text { response (13) }\end{array}$ \\
\hline & Favipiravir & $\begin{array}{l}\mathrm{EC}_{50}=61.88 \mu \mathrm{M}, \mathrm{CC}_{50}>400 \mu \mathrm{M}, \mathrm{SI}>6.46 ; \mathrm{MOI}= \\
0.05,48 \mathrm{hpi} \text {, Vero } \mathrm{E6}(12)\end{array}$ & $\begin{array}{l}\text { Modest reduction of viral } \\
\text { load in hamsters (14) }\end{array}$ & $\begin{array}{l}\text { Higher recovery rate and faster viral clearance } \\
\text { in moderate COVID-19 }(15,16) \text {; cannot rescue } \\
\text { severe COVID-19 }(16) \\
\text { Approval in China, Russia, and India (17) }\end{array}$ \\
\hline & Remdesivir & $\begin{array}{l}\mathrm{EC}_{50}=0.77 \mu \mathrm{M}, \mathrm{CC}_{50}>100 \mu \mathrm{M}, \mathrm{SI}>129.87 ; \mathrm{MOI}= \\
0.05,48 \text { hpi, Vero } \mathrm{E} 6(12)\end{array}$ & $\begin{array}{l}\text { Improved clinical } \\
\text { outcome in rhesus } \\
\text { macaques (20) }\end{array}$ & $\begin{array}{l}\text { Shorter time to recovery (18); few clinical } \\
\text { benefits in severe COVID-19 (19) } \\
\text { US FDA approval in hospitalized patients (21) }\end{array}$ \\
\hline & $\begin{array}{l}\text { Sofosbuvir \& HCV } \\
\text { NS5A inhibitors }\end{array}$ & $\begin{array}{l}\text { Sofosbuvir: } \\
\mathrm{EC}_{50}=6.2 \mu \mathrm{M}, \mathrm{CC}_{50}=381 \mu \mathrm{M}, \mathrm{SI}=61 ; \mathrm{MOI}=0.1 \\
48 \mathrm{hpi}, \mathrm{Huh}-7(23) \\
\mathrm{EC}_{50}=9.5 \mu \mathrm{M}, \mathrm{CC}_{50}=512 \mu \mathrm{M}, \mathrm{SI}=54 ; \mathrm{MOI}=0.1 \\
48 \mathrm{hpi}, \text { Calu-3 }(23) \\
\text { Daclatasvir: } \\
\mathrm{EC}_{50}=0.8 \mu \mathrm{M}, \mathrm{CC}_{50}=31 \mu \mathrm{M}, \mathrm{SI}=39 ; \mathrm{MOI}=0.01 \\
24 \mathrm{hpi}, \mathrm{Vero}(23) \\
\mathrm{EC}_{50}=0.6 \mu \mathrm{M}, \mathrm{CC}_{50}=6.1 \mu \mathrm{M}, \mathrm{SI}=47 ; \mathrm{MOI}=0.1 \\
48 \mathrm{hpi}, \mathrm{Huh}-7(23) \\
\mathrm{EC}_{50}=1.1 \mu \mathrm{M}, \mathrm{CC}_{50}=3.0 \mu \mathrm{M}, \mathrm{SI}=34 ; \mathrm{MOI}=0.1 \\
48 \mathrm{hpi}, \text { Calu-3 }(23)\end{array}$ & $\mathrm{N} / \mathrm{A}$ & $\begin{array}{l}\text { Sofosbuvir/daclatasvir: faster recovery and } \\
\text { lower mortality (22) } \\
\text { Sofosbuvir/velpatasvir: in progress }\end{array}$ \\
\hline \multirow[t]{6}{*}{$\begin{array}{l}\text { Protease } \\
\text { inhibitor }\end{array}$} & Boceprevir & $\begin{array}{l}\mathrm{EC}_{50}=1.31 \mu \mathrm{M}, \mathrm{CC}_{50}>100 \mu \mathrm{M}, \mathrm{SI}>76.3 ; 60 \\
\mathrm{TCID}_{50}, 5 \mathrm{dpi} \text {, Vero } 76(24)\end{array}$ & $\mathrm{N} / \mathrm{A}$ & $N / A$ \\
\hline & $\begin{array}{l}\alpha \text {-ketoamide } \\
\text { (compound 13b) }\end{array}$ & $\begin{array}{l}\mathrm{EC}_{50}=4 \sim 5 \mu \mathrm{M}, \mathrm{CC}_{50} \text { unknown; } \mathrm{MOI}=0.05 \text {, Calu-3 } \\
\text { (25) }\end{array}$ & $\mathrm{N} / \mathrm{A}$ & $N / A$ \\
\hline & $\begin{array}{l}\text { Peptidomimetic } \\
\text { aldehydes 11a \& } \\
11 b^{\star}\end{array}$ & $\begin{array}{l}\frac{11 \mathrm{a}:}{\mathrm{EC}_{50}}=0.53 \mu \mathrm{M}, \mathrm{CC}_{50}>100 \mu \mathrm{M}, \mathrm{SI}>189 ; \mathrm{MOI}= \\
0.05,24 \text { hpi, Vero E6 (26) } \\
\frac{11 \mathrm{~b}:}{\mathrm{EC}_{50}}=0.72 \mu \mathrm{M}, \mathrm{CC}_{50}>100 \mu \mathrm{M}, \mathrm{SI}>139 ; \mathrm{MOI}= \\
0.05,24 \text { hpi, Vero E6 (26) }\end{array}$ & $\mathrm{N} / \mathrm{A}$ & $\mathrm{N} / \mathrm{A}$ \\
\hline & Calpain inhibitors* & $\begin{array}{l}\text { Calpain inhibitor II: } \\
\mathrm{EC}_{50}=2.07 \mu \mathrm{M}, \mathrm{CC}_{50}>100 \mu \mathrm{M}, \mathrm{SI}>48.3 ; 60 \\
\mathrm{TCID}_{50}, 5 \mathrm{dpi} \text {, Vero } 76(24) \\
\text { Calpain inhibitor XII: } \\
\mathrm{EC}_{50}=0.49 \mu \mathrm{M}, \mathrm{C} \mathrm{C}_{50}>100 \mu \mathrm{M}, \mathrm{SI}>204 ; 60 \mathrm{TCID}_{50} \text {, } \\
5 \mathrm{dpi} \text {, Vero } 76(24)\end{array}$ & $\mathrm{N} / \mathrm{A}$ & $\mathrm{N} / \mathrm{A}$ \\
\hline & $\begin{array}{l}\text { Lopinavir/ } \\
\text { Ritonavir (LPV/r) }\end{array}$ & $\begin{array}{l}\mathrm{EC}_{50}=26 \mu \mathrm{M}, \mathrm{CC}_{50}=49.75 \mu \mathrm{M}, \mathrm{SI}=1.9 ; \mathrm{MOI}= \\
0.02,48 \mathrm{hpi} \text {, Vero E6 (29) }\end{array}$ & $\begin{array}{l}\text { Lower clinical scores but } \\
\text { no effect on viral titers in } \\
\text { ferrets (30) }\end{array}$ & No clinical benefits $(27,28)$ \\
\hline & $\begin{array}{l}\text { Darunavir/ } \\
\text { Cobicistat (DRV/c) }\end{array}$ & $\begin{array}{l}\mathrm{EC}_{50}>100 \mu \mathrm{M} \text { (inactive), } \mathrm{CC}_{50}>100 \mu \mathrm{M} ; \mathrm{MOI}=0.01 \\
48 \mathrm{hpi}, \text { Caco-2 (32) }\end{array}$ & $\mathrm{N} / \mathrm{A}$ & No impact on viral clearance (31) \\
\hline $\begin{array}{l}\text { Host- } \\
\text { targeting } \\
\text { agent }\end{array}$ & Interferons (IFNs) & 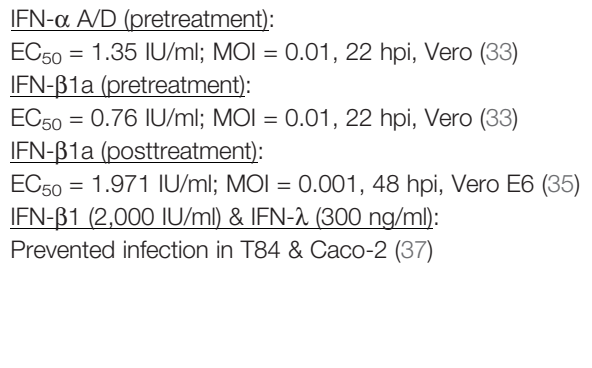 & $\mathrm{N} / \mathrm{A}$ & $\begin{array}{l}\text { IFN- } \alpha 2 \mathrm{~b} \text { (aerosol): Faster viral clearance and } \\
\text { reduced inflammatory response (34) } \\
\text { IFN- } \beta 1 \mathrm{~b} \text { (subcutaneous), LPV/r, ribavirin: Faster } \\
\text { viral clearance and reduced inflammatory } \\
\text { response (13) } \\
\text { IFN- } \beta 1 \mathrm{a} \text { (subcutaneous): Increased discharge } \\
\text { rate and decreased mortality in severe COVID- } \\
19 \text { (36) } \\
\text { IFN- } \text { (aerosol) plus TFF2: Faster recovery, viral } \\
\text { clearance, and discharge (38) } \\
\text { IFN- } \lambda \text { : In progress }\end{array}$ \\
\hline
\end{tabular}


TABLE 1 | Continued

\begin{tabular}{|c|c|c|c|c|}
\hline \multirow[t]{2}{*}{ Class } & \multirow[t]{2}{*}{ Drug } & \multicolumn{3}{|c|}{ Antiviral effect } \\
\hline & & In vitro & In vivo & RCT \\
\hline & $\begin{array}{l}\text { Serine protease } \\
\text { inhibitors }\end{array}$ & $\begin{array}{l}\text { Camostat: } \mathrm{EC}_{50}=87 \mathrm{nM} \text {, entry in Calu-3 (39) } \\
\text { Nafamostat: } \mathrm{EC}_{50}=5 \mathrm{nM} \text {, entry in Calu-3 (39) }\end{array}$ & $\mathrm{N} / \mathrm{A}$ & In progress \\
\hline & Dexamethasone & N/A & $\mathrm{N} / \mathrm{A}$ & $\begin{array}{l}\text { Lower mortality in COVID-19 patients who } \\
\text { required respiratory support (40) }\end{array}$ \\
\hline & Losartan & N/A & $\mathrm{N} / \mathrm{A}$ & In progress \\
\hline & $\begin{array}{l}\text { Chloroquine (CQ)/ } \\
\text { Hydroxychloroquine } \\
\text { (HCQ) }\end{array}$ & 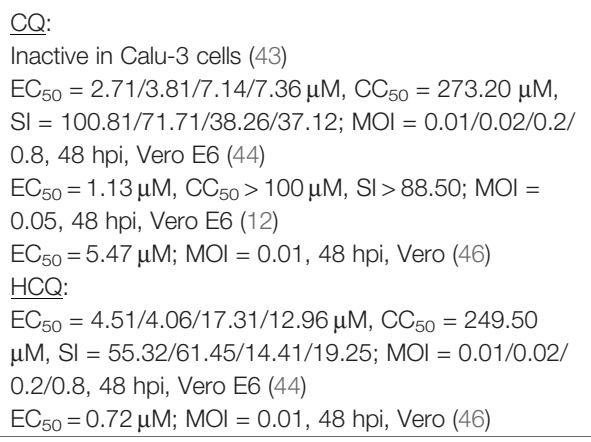 & $\begin{array}{l}\text { CQ: N/A } \\
\text { HCQ: } \\
\text { Lower clinical scores but } \\
\text { no effect on viral titers in } \\
\text { ferrets }(30) \\
\text { No antiviral activity in } \\
\text { hamsters }(14,45) \\
\text { No antiviral activity in } \\
\text { macaques }(45,47)\end{array}$ & No clinical benefits $(41,42)$ \\
\hline & Arbidol & $\begin{array}{l}\mathrm{EC}_{50}=4.11 \mu \mathrm{M}, \mathrm{CC}_{50}=31.79 \mu \mathrm{M}, \mathrm{SI}=7.73 ; \mathrm{MOI}= \\
0.05,48 \mathrm{hpi} \text {, Vero } \mathrm{E} 6(49)\end{array}$ & $\mathrm{N} / \mathrm{A}$ & No clinical benefits (48) \\
\hline
\end{tabular}

$N / A$, not available; $R C T$, randomized controlled trial.

*SARS-CoV-2 Mpro inhibitors.

IFN- $\alpha$ had a higher improvement rate in their chest imaging and faster viral clearance compared to the control group receiving $\mathrm{LPV} / \mathrm{r}$ plus IFN- $\alpha$ (15). A randomized open-label controlled trial (ChiCTR2000030254) compared favipiravir treatment with arbidol, an indole-derivative small molecule anti-influenza virus drug, and reported in a preprint that moderate COVID19 patients treated with favipiravir had higher recovery rate and required less auxiliary (16). However, neither of the two drugs effectively rescued severe disease patients, indicating the restricted use of favipiravir in moderate COVID-19 patients to prevent deterioration (16). Based on the preliminary results, favipiravir has been approved for the treatment of COVID-19 in China, Russia, and India (17).

\section{Remdesivir}

Remdesivir (GS-5734) is a broad-spectrum adenosine analog prodrug that inhibits early viral RNA synthesis by causing delayed chain termination (69-72). The compound exhibits antiviral activities against Ebola virus $(69,71,73)$, respiratory syncytial virus (RSV) $(69,73)$, Nipah virus, parainfluenza virus (73), and a panel of coronaviruses including endemic humanCoVs, SARS-CoV, MERS-CoV, bat-CoVs, and murine hepatitis virus (MHV) (74-76). The drug has been evaluated in clinical trials with Ebola virus disease patients, but it appeared less effective than Ebola virus-specific monoclonal antibodies (77).

In coronavirus models, it has been demonstrated that prophylactic or early therapeutic administration of remdesivir is critical for inhibiting viral replication. Remdesivir given 1 day pre-infection and 1 day post-infection (dpi) in SARS-CoVinfected mice both reduced the lung viral titer and SARS-CoV- induced lung pathology, while treatment given 2 dpi only reduced viral load without improving disease outcome (74). Remdesivir treatments in MERS-CoV-infected mice (78) and rhesus macaques (79) also demonstrated that both prophylactic and early therapeutic treatments decreased the viral load, clinical signs, and pathology, with the prophylactic approach being more protective.

As for SARS-CoV-2, in vitro data indicate high antiviral potency of remdesivir $\left(\mathrm{EC}_{50}=0.77 \mu \mathrm{M}\right.$, SI > 129.87) (12), and the drug improved clinical outcome of SARS-CoV-2-infected rhesus macaques when given at 12 hours post-infection (hpi) (20). The drug has received Emergency Use Authorization (EUA) in the United States (US) as well as statutory approval in Japan for the treatment of COVID-19, based on results from phase 3 trials supported by the US National Institute of Allergy and Infectious Diseases (NIAID) (NCT04280705; Adaptive COVID-19 Treatment Trial, ACTT 1) and Gilead (NCT04292899; SIMPLE trial) $(80,81)$. ACTT 1 is a multi-center, double-blind, randomized, placebo-controlled trial which suggested that 10-day remdesivir shortens the time to recovery but has no significant impact on mortality based on its preliminary results (18), whereas SIMPLE trial compared a 5-day course and a 10-day course of remdesivir and reported that the clinical outcomes were similar in severe COVID-19 patients (82). However, a recently published multi-center, randomized, placebo-controlled trial found that remdesivir did not lower the viral load and did not provide clinical benefits in patients with severe COVID-19 (19). Nonetheless, the US FDA has approved the use of remdesivir in hospitalized patients in October 2020, but the rest of the population is still covered under the EUA issued in May 2020 (20). 
On the other hand, Yan and Muller recently suggested that the parental nucleoside of remdesivir, GS-441524, may be superior to remdesivir for the treatment of COVID-19 based on their pharmacokinetic profiles (83). Bioactivation of remdesivir requires enzymes that are predominantly expressed in the liver rather than the lungs and could possibly explain the liver-related adverse effects in remdesivir-treated COVID-19 patients. Additionally, esterases and phosphatases in the serum facilitates premature hydrolysis of the McGuigan prodrug on remdesivir, resulting in the presence of GS-441524 as the predominant species in serum after remdesivir administration $(69,20)$. Therefore, further investigation of GS441524 for the treatment of COVID-19 could be considered to prevent deferential bioactivation and off-target effect of the prodrug (83).

\section{Sofosbuvir and HCV NS5A Inhibitors}

Sofosbuvir is a licensed uridine nucleotide analog prodrug that competitively blocks HCV NS5B polymerase and causes RNA chain termination (84). Since SARS-CoV-2 and HCV are both positive-sense RNA viruses, the use of $\mathrm{HCV}$ polymerase inhibitors is expected to be effective for SARS-CoV-2 to some extent. Clinically used with sofosbuvir for the treatment of hepatitis C (85), daclatasvir is one of the HCV NS5A inhibitors that interferes with HCV replication complex (86).

In silico docking analyses reported that sofosbuvir bound to SARS-CoV (87) and SARS-CoV-2 (88) RdRp active sites, suggesting potential antiviral activities. In vitro data displayed on preprint server demonstrated that sofosbuvir did not inhibit SARS-CoV-2 in Vero cells, but was active in human hepatoma Huh-7 cells $\left(\mathrm{EC}_{50}=6.2 \mu \mathrm{M}, \mathrm{SI}=61\right)$ and human lung adenocarcinoma Calu-3 cells $\left(\mathrm{EC}_{50}=9.5 \mu \mathrm{M}\right.$, SI $\left.=54\right)(23)$. Meanwhile, daclatasvir inhibited SARS-CoV-2 in all three cell lines $\left(\mathrm{EC}_{50}=0.6 \sim 1.1 \mu \mathrm{M}, \mathrm{SI}=34 \sim 47\right)(23)$. Several trials are ongoing to evaluate sofosbuvir/daclatasvir in COVID-19 patients. A small multi-center, double-blind, randomized, controlled trial (IRCT20200128046294N2) was recently completed and reported a faster recovery in moderate to severe COVID-19 patients who received sofosbuvir/daclatasvir plus $\mathrm{LPV} / \mathrm{r}$, compared to those who received only LPV/r (22). Furthermore, meta-analysis of the combined results from this study and the other ones in Iran favored the use of sofosbuvir/ daclatasvir with significantly reduced time to recovery and mortality (22). A larger multi-center, double-blind, randomized, controlled trial (IRCT20200624047908N1) is underway to validate the results. In addition, the combination of sofosbuvir/velpatasvir (another HCV NS5A inhibitor) will be evaluated in another single-center, single-blind, randomized, controlled trial (IRCT20130812014333N145) (89).

\section{Protease Inhibitors}

\section{HCV NS3/4A Protease Inhibitors}

Based on several preliminary structural analyses in preprints (90, 91), HCV NS3/4A shares a three-dimensional similarity with the SARS-CoV-2 Mpro, suggesting a potential of investigating HCV protease inhibitors in SARS-CoV-2 infection. Several licensed (simeprevir, paritaprevir, grazoprevir, glecaprevir, boceprevir, telaprevir) and investigational (sovaprevir, vaniprevir, danoprevir) $\mathrm{HCV}$ protease inhibitors were predicted to bind to the SARS-CoV-2 Mpro active site $(90,91)$. Enzymatic and binding assays further revealed that boceprevir $\left(\mathrm{IC}_{50}=4.13 \mu \mathrm{M}\right)$ and narlaprevir (another licensed $\mathrm{HCV}$ protease inhibitor; $\left.\mathrm{IC}_{50}=4.73 \mu \mathrm{M}\right)$ inhibited Mpro more potently than simeprevir $\left(\mathrm{IC}_{50}=13.74 \mu \mathrm{M}\right)$, and the antiviral activity of boceprevir against SARS-CoV-2 $\left(\mathrm{EC}_{50}=1.31 \mu \mathrm{M}, \mathrm{SI}>76.3\right)$ was confirmed in vitro (24). Currently, there are no large randomized trials evaluating FDA-approved HCV protease inhibitors in COVID-19 patients. Nonetheless, agents such as boceprevir which is already licensed and displayed anti-SARS-CoV-2 in vitro may be suitable candidates for clinical or at least in vivo studies.

\section{CoV Mpro and PLpro Inhibitors}

Protease inhibitors designed for coronaviruses are also being investigated. These drug candidates could be more specific but are mostly preclinical. Some examples with anti-SARS-CoV-2 activity shown in vitro are described here. $\alpha$-ketoamides are a class of peptidomimetic compounds that were synthesized to inhibit coronavirus Mpro and enterovirus 3C protease, exhibiting antiviral effects against SARS-CoV $\left(\mathrm{EC}_{50}=5.8 \mu \mathrm{M}\right)$, MERS-CoV $\left(\mathrm{EC}_{50}=0.0047 \mu \mathrm{M}\right), \mathrm{HCoV}-229 \mathrm{E}\left(\mathrm{EC}_{50}=11.8 \mu \mathrm{M}\right)$, Enterovirus $71\left(\mathrm{EC}_{50}=9.8 \mu \mathrm{M}\right)(92)$, and the current SARSCoV-2 (compound 13b, $\mathrm{EC}_{50}=4 \sim 5 \mu \mathrm{M}$ ) (25). Peptidomimetic aldehydes $11 \mathrm{a}$ and $11 \mathrm{~b}$ were also designed and synthesized based on the structure of SARS-CoV-2 Mpro, and both compounds potently inhibited SARS-CoV-2 (11a: $\mathrm{EC}_{50}=0.53 \mu \mathrm{M}, \mathrm{SI}>189$; 11b: $\mathrm{EC}_{50}=0.72 \mu \mathrm{M}, \mathrm{SI}>139$ ), with compound 11a displaying better pharmacokinetic profile (26). The bisulfite adduct GC-376, an investigational veterinary drug that inhibits feline infectious peritonitis virus Mpro and a number of other viruses (93-95), also inhibits SARS-CoV-2 Mpro $\left(\mathrm{IC}_{50}=0.03 \mu \mathrm{M}\right)$ and effectively precludes SARS-CoV-2 infection $\left(\mathrm{EC}_{50}=3.37 \mu \mathrm{M}\right.$, SI > 29.7) (24). The same study also revealed two other SARS-CoV-2 Mpro inhibitory compounds, calpain inhibitor II $\left(\mathrm{IC}_{50}=0.97 \mu \mathrm{M}\right)$ and XII $\left(\mathrm{IC}_{50}=0.45 \mu \mathrm{M}\right)$, that exhibit anti-SARS-CoV-2 activity $\left(\mathrm{EC}_{50}=2.07 \mu \mathrm{M}\right.$, SI > 48.3 and $\mathrm{EC}_{50}=0.49 \mu \mathrm{M}$, SI > 204, respectively) (24). The high potency and specificity of these compounds imply their potential to be further investigated and developed as clinical drugs. In addition, PLpro inhibitors that have exhibited antiviral activities against other CoVs may be worth investigating due to the conserved structures of $\mathrm{CoV}$ PLpro (96).

\section{Helicase Inhibitors}

Due to the predicted similarity and conserved active sites in the nsp13 helicase of SARS-CoV and SARS-CoV-2, helicase inhibitors previously shown to inhibit SARS-CoV could be of potential value (97). For example, the adamantane-derived Bananin was shown to inhibit SARS-CoV ATPase $\left(\mathrm{IC}_{50}=2.3\right.$ $\mu \mathrm{M})$ and helicase $\left(\mathrm{IC}_{50}=3.0 \mu \mathrm{M}\right)$ activities and viral replication $\left(\mathrm{EC}_{50}<10 \mu \mathrm{M}, \mathrm{CC}_{50}>300 \mu \mathrm{M}\right)$ (98). Another compound, SSYA10-001, was also shown to inhibit SARS-CoV helicase $\left(\mathrm{IC}_{50}=\right.$ $5 \mu \mathrm{M})$ and replication $\left(\mathrm{EC}_{50}=8.95 \mu \mathrm{M}, \mathrm{CC}_{50}>250 \mu \mathrm{M}\right)(99)$. 
SSYA10-001 also inhibits the replication of MERS-CoV $\left(\mathrm{EC}_{50} \sim\right.$ $25 \mu \mathrm{M})$ and $\mathrm{MHV}\left(\mathrm{EC}_{50} \sim 12 \mu \mathrm{M}\right)$, which have conserved active sites in their helicases as that of SARS-CoV (100). These compounds, however, have not been examined in SARS-CoV-2 infection models and merits further investigation.

\section{Lopinavir/Ritonavir}

$\mathrm{LPV} / \mathrm{r}$ is a combination of two protease inhibitors used for the treatment of HIV infection (101-103). Lopinavir is an uncleavable peptidomimetic of the linkage peptide in HIV gagpol polyprotein that binds to HIV protease and inhibits its activity. Ritonavir, also a HIV protease inhibitor, mainly functions as an inhibitor of cytochrome P450 CYP3A4 isoenzyme in LPV/r. Low-dose ritonavir in the coformulation improves the pharmacokinetic profile of lopinavir through inhibition of its CYP3A-mediated metabolism (100-103).

Previously investigated during the SARS outbreak, LPV/r demonstrated synergistic effect in combination with ribavirin, and addition of LPV/r to ribavirin and corticosteroid was shown to improve the clinical outcome compared to the control group without LPV/r treatment (60). Another retrospective cohort study also indicates that the addition of $\mathrm{LPV} / \mathrm{r}$ to ribavirin and corticosteroid reduced the mortality rate and intubation rate compared to a matched cohort receiving only ribavirin and corticosteroid (104). In silico analysis suggested that $\mathrm{LPV} / \mathrm{r}$ interacts with SARS-CoV 3CL protease and binds to its active site, forming a flap closing conformation that has been observed in $\mathrm{HIV}-1$ protease when an inhibitor is bound (105).

As for its effect on MERS-CoV, LPV/r plus IFN- $\beta$ combination could not prevent mice from MERS-CoV infection, but as a treatment improved pulmonary function without affecting the viral load or severe lung pathology, indicating a less effective role than remdesivir (78). However, in a marmoset MERS-CoV model, LPV/r alone and LPV/r plus IFN- $\beta$ were reported to reduce lung viral load and improve clinical outcome in comparison with untreated animals (106). A randomized, placebo-controlled, double-blind trial (NCT02845843; MIRACLE) to investigate the LPV/r and IFN- $\beta 1 \mathrm{~b}$ combination in hospitalized MERS patients was initiated and just recently completed (107), but the results are not yet available.

In the context of SARS-CoV-2 infection, despite limited preclinical data in Vero E6 cells $\left(\mathrm{EC}_{50}=26 \mu \mathrm{M}\right.$, SI = 1.9) (29) and in ferrets (30), several clinical trials were underway to evaluate the effect of LPV/r in COVID-19 patients. A singlecenter, randomized, controlled, open-label trial in China (ChiCTR2000029308) compared the standard of care with $\mathrm{LPV} / \mathrm{r}$ plus standard of care for 14 days in severe COVID-19 patients but found no significant difference in the median time to clinical improvement, 28-day mortality, and length of ICU stay, despite numerical reductions (27). The study design and the small sample size prompted a discussion that results from this study were statistically underpowered and inconclusive to exclude further investigation of the drug (108-113), suggesting the need to initiate trials with bigger sample sizes and earlier treatment. However, as a participant of the WHO Solidarity Trial, the RECOVERY trial conducted in the United Kingdom (EudraCT 2020-001113-21/NCT04381936) reported that LPV/r monotherapy provided no clinical benefit in hospitalized COVID-19 patients (28). The study compared 1596 patients randomized to $\mathrm{LPV} / \mathrm{r}$ treatment and 3376 patients who received only standard of care and found no significant difference in the 28-day mortality, the risk of progression to mechanical ventilation, and length of hospital stay (28). Along with other interim trial results, WHO has announced to discontinue the treatment arm of LPV/r monotherapy for COVID-19 patients in the Solidarity Trial (50).

\section{Darunavir/Cobicistat}

The nonpeptidic drug darunavir (TMC114) is another licensed HIV protease inhibitor. Darunavir has a higher binding affinity and potency over other HIV protease inhibitors $(114,115)$, and it prevents the viral protease from dimerizing and obtaining its proteolytic activity (116). Darunavir is often prescribed with cobicistat as a CYP3A inhibitor (DRV/c) for treatment of HIV-1 infection $(117,118)$.

In contrast to $\mathrm{LPV} / \mathrm{r}, \mathrm{DRV} / \mathrm{c}$ was never tested for its antiviral activity in SARS-CoV or MERS-CoV infection. As for its effect against SARS-CoV-2 in vitro, the drug did not show any inhibition in human colorectal adenocarcinoma Caco-2 cells $\left(\mathrm{EC}_{50}>100 \mu \mathrm{M}\right)(32)$. Despite the lack of preclinical evidence, a few clinical trials were initiated to evaluate its effect in COVID19 patients. Of which, results from a single-center, randomized, open-label controlled trial in China (NCT04252274) concluded that 5-day DRV/c treatment had no impact on viral clearance compared to the control group in mild COVID-19 patients (31), indicating its ineffectiveness for the disease.

\section{Host-Targeting Agents Interferons}

The antiviral activity of IFNs has been well studied in coronaviruses. For SARS-CoV, IFN- $\beta 1 \mathrm{~b}$ showed the highest in vitro antiviral activity $\left(\mathrm{EC}_{50}=9.2\right.$ and $21.0 \mathrm{IU} / \mathrm{ml}, \mathrm{SI}>1,087$ and 476 against the Hong Kong and FFM-1 isolates, respectively) compared to IFN- $\alpha 2 \mathrm{~b}\left(\mathrm{EC}_{50}=880\right.$ and $1,530 \mathrm{IU} / \mathrm{ml}, \mathrm{SI}>11.4$ and 6.5) and IFN- $\gamma 1 \mathrm{~b}\left(\mathrm{EC}_{50}>10,000 \mathrm{IU} / \mathrm{ml}\right.$ for both isolates) in Caco-2 cells (119). In vivo, IFN- $\alpha$ B/D treatment starting 4 hpi for 3 days successfully reduced viral titer in BALB/c mice (120). In another study, a single dose of IFN- $\beta$ given at 6 hpi protected the mice from lethal SARS-CoV challenge, preventing the delayed type I IFN signaling that contributes to SARS immunopathology (121). In an uncontrolled small clinical study, patients who received IFN alfacon-1 for 8-13 days in addition to corticosteroid treatment exhibited better clinical outcome than those who were treated with corticosteroid alone (122).

Similarly for MERS-CoV, IFN- $\beta$ also displayed the highest potency amongst other IFNs against MERS-CoV in Vero cells $(58,123)$. On the other hand, IFN- $\lambda$ was shown to inhibit MERS-CoV replication in human respiratory epithelium (124). 
In animal studies, marmosets treated with IFN- $\beta 1 \mathrm{~b} 8 \mathrm{~h}$ after viral challenge exhibited better clinical outcome (106). IFN- $\alpha 2 b$ and ribavirin treatment started 8 hpi also improved the clinical outcome in rhesus macaques with MERS-CoV challenge (125). In one clinical trial in MERS patients, IFN treatment (IFN- $\alpha 2 \mathrm{a}$, IFN- $\alpha 2 b$, or IFN- $\beta 1 a)$ alone or with ribavirin did not improve the survival rate or viral clearance (126); however, $60 \%$ of the IFN-treated patients also received corticosteroid, which might have suppressed IFN signaling (127). The therapeutic effect of IFN- $\beta 1 \mathrm{~b}$ plus $\mathrm{LPV} / \mathrm{r}$ is yet to be determined from the results of the MIRACLE trial (107).

As for SARS-CoV-2, IFN- $\alpha$ A/D $\left(\mathrm{EC}_{50}=1.35 \mathrm{IU} / \mathrm{ml}\right)$ and IFN- $\beta 1 \mathrm{a}\left(\mathrm{EC}_{50}=0.76 \mathrm{IU} / \mathrm{ml}\right)$ pretreatment inhibited viral replication in vitro at low $\mathrm{EC}_{50}$ values (33). When administered at $1 \mathrm{hpi}$, IFN- $\beta 1 \mathrm{a}$ also inhibited viral infection in Vero E6 cells $\left(\mathrm{EC}_{50}=1.971 \mathrm{IU} / \mathrm{ml}\right)(35)$, although the MOI used was relatively low. In human colorectal adenocarcinoma T84 and Caco- 2 cells and human colon organoids, both type I (IFN- $\beta 1$ ) and type III (IFN- $\lambda$ ) IFNs prevented SARS-CoV-2 infection (37). Interestingly, SARS-CoV-2 infection significantly upregulated the production of IFN- $\lambda$ but not IFN- $\beta 1$ in colon organoids, suggesting a critical role of type III IFN response in controlling the infection in human intestinal cells (37).

In recent clinical studies, IFN monotherapy and combination therapies were investigated. A study in the Union Hospital in Wuhan suggested that IFN- $\alpha 2 b$ aerosol with or without arbidol reduced the duration of viral clearance and inflammatory response compared to arbidol monotherapy (34). A triple combination of IFN- $\beta 1 \mathrm{~b}$ (subcutaneous injection), LPV/r, and ribavirin also led to similar results compared to $\mathrm{LPV} / \mathrm{r}$ monotherapy in a multi-center, open-label, randomized, controlled trial (NCT04276688) (13). Another study reported that the addition of IFN- $\beta 1$ a to standard of care did not improve the overall clinical outcome but increased the discharge rate on day 14 and decreased the 28-day mortality in patients with severe COVID-19 (36). More trials of type I IFNs in combination with LPV/r (e.g., WHO Solidarity DisCoVeRy trial) or remdesivir (e.g., NIAID ACTT 3), as well as trials of IFN- $\lambda$ (NCT04354259)are ongoing. In addition, a pilot study reported that inhalation of IFN-K plus trefoil factor 2 (TFF2) shortened the time of symptom relief, viral clearance, and hospitalization (38). These findings suggest that IFNs are a promising candidate for COVID-19 treatment. Notably, the route of IFN administration will be a critical issue to consider to achieve the best bioavailability in the target organs (127).

\section{Serine Protease Inhibitors}

Due to the essential role of serine protease TMPRSS2 in activating SARS-CoV-2 spike for its entry on the cell membrane (7), serine protease inhibitors are also an attractive group of drugs. Camostat, a serine protease inhibitor approved for the treatment of chronic pancreatitis in Japan (128), has been shown to inhibit SARS-CoV entry (129) and partially protected mice from lethal challenge (130). It was recently reported that camostat $\left(\mathrm{EC}_{50}=87 \mathrm{nM}\right)$ and another serine protease inhibitor nafamostat $\left(\mathrm{EC}_{50}=5 \mathrm{nM}\right)$ used as an anticoagulant were able to inhibit SARS-CoV-2 entry at low concentrations (39). Several clinical trials investigating these two drugs are underway.

\section{Dexamethasone}

Dexamethasone is a licensed corticosteroid commonly used for its anti-inflammatory effects (131). The use of corticosteroids in viral pneumonia and acute respiratory distress syndrome has been controversial $(132,133)$. Although theoretically corticosteroids could alleviate the inflammation of viral pneumonia, several previous studies demonstrated that corticosteroid treatment could delay viral clearance and induce multiple complications, providing no clinical benefits (134). However, preliminary results from the RECOVERY trial suggested that the use of dexamethasone lowered the 28-day mortality in hospitalized COVID-19 patients who required respiratory support (40). Noteworthy, no benefits were observed in patients who did not need oxygen support upon admission (40). Based on this preliminary results, dexamethasone is now recommended for hospitalized COVID-19 patients who are mechanically ventilated or require oxygen supplement (135).

\section{Losartan}

Losartan is an angiotensin II receptor blocker (ARB) for the treatment of hypertension and diabetic nephropathy. It has been shown that losartan increases the expression level of ACE2 (136, 137), which has a protective role in severe acute lung injury (138). A previous study found that SARS-CoV infection and the viral spike protein downregulate ACE2 expression in the lungs, causing severe lung injury in infected mice (139). The administration of losartan reduced the acute severe lung injury and pulmonary edema in SARS-CoV spike-treated mice (139). Due to the similar receptor usage and pathogenesis of SARS-CoV-2 and SARS-CoV, losartan has been proposed as a tentative treatment for COVID19 (140, 141). However, increasing ACE2 expression also raises the concern of enhancing SARS-CoV-2 infection, thus careful monitoring and safety evaluation are mandatory. Clinical data of losartan's therapeutic effect in COVID-19 patients are not yet available. In addition, its use in infected patients with cardiovascular diseases should be continued due to a current lack of evidence for its discontinuation (142).

\section{Chloroquine and Hydroxychloroquine}

CQ and its derivative HCQ are antimalarial drugs that have also exhibited broad-spectrum antiviral activities by interfering with the endosome-mediated viral entry and the late stages of viral replication, in steps that require an acidic environment (143). CQ and HCQ were reported to possess anti-SARS-CoV activities in vitro $(120,144)$ but appeared ineffective in mouse model (104). The drugs also demonstrated antiviral effects against SARS-CoV-2 in Vero and Vero E6 cells $(12,44,46)$ but not in Calu-3 cells (43), and their benefits in vivo were highly controversial. HCQ lowered the clinical scores in ferrets but did not affect the viral titers (30), and no antiviral activity was observed in hamsters and macaques $(14,45,47)$. Based on the antiviral activities shown in vitro and the earliest literature including a brief clinical report in China (145) and the manuscript from Gautret et al., which was later found to have serious methodological issues (146), CQ and 
HCQ received an EUA in March 2020. However, the positive results were not always replicable in subsequent clinical trials, and the higher quality data from randomized controlled trials suggested that the drugs did not provide any clinical benefits (41, 42). This led to the revocation of EUA (147) and discontinuation of clinical trials of the CQ/HCQ arm (50).

\section{Arbidol}

Arbidol is a small molecule indole-derivative approved in Russia and China for prophylaxis and treatment against influenza virus infection. The drug inhibits viral infection via its intercalation into membrane lipids, which interferes with membrane fusion involved in multiple steps of viral life cycle $(148,149)$. Previous in vitro studies indicated that arbidol is capable of curbing SARS$\mathrm{CoV}$ replication (150) and was the most efficacious antiinfluenza drug against SARS-CoV-2 $\left(\mathrm{EC}_{50}=4.11 \mu \mathrm{M}\right.$, SI = 7.73) (49). Results from several retrospective trials suggested that arbidol $(151,152)$ or the combination of arbidol and LPV/r (153) could be beneficial. However, a randomized controlled trial assessing LPV/r and arbidol monotherapies in mild/moderate COVID-19 patients found that both treatments had little clinical benefits as compared to supportive care, with no significant difference in the viral negative conversion rate and symptom improvement (48). Therefore, the clinical effect of arbidol remains questionable.

\section{CURRENT CHALLENGES AND FUTURE PERSPECTIVE}

In order to effectively control the ongoing SARS-CoV-2 global pandemic, vaccination and the development of therapeutics are both indispensable. While a few vaccine candidates are being rolled out, the supply is still limited, and a tremendous effort and amount of time are required to achieve sufficient immunization coverage. Hence, rapid identification of efficacious antivirals remains a top priority to improve management strategies for newly acquired or currently existing infections and minimize fatalities in COVID-19 patients. This highlights the need to employ high-throughput screening and structure-based analyses to fast track the identification of potential candidates. Of note, it is now evident that drugs with promising antiviral activities in vitro do not necessarily exert effectiveness in animal

\section{REFERENCES}

1. Cui J, Li F, Shi ZL. Origin and evolution of pathogenic coronaviruses. Nat Rev Microbiol (2019) 17(3):181-92. doi: 10.1038/s41579-018-0118-9

2. Center for Systems Science and Engineering at Johns Hopkins University. COVID-19 Dashboard (2020). Available at: https://coronavirus.jhu.edu/ map.html (Accessed 03 September 2020).

3. Rothan HA, Byrareddy SN. The epidemiology and pathogenesis of coronavirus disease (COVID-19) outbreak. I Autoimmun (2020) 109:102433. doi: 10.1016/j.jaut.2020.102433

4. Center for Systems Science and Engineering at Johns Hopkins University. Mortality Analyses (2020). Available at: https://coronavirus.jhu.edu/data/ mortality (Accessed 15 December 2020). models or in humans. Previous experiences in CQ/HCQ (154) and LPV/r (30) have provided an insight that animal studies may help predict the drugs' effect in a more realistic scenario, although the outcomes can vary between animals and humans. In terms of interpreting clinical data, the design of trials such as the inclusion criteria, treatment assignment, administration route, co-existing treatments, endpoints, and methods of statistical analysis should all be carefully reviewed.

Besides the efficient use of repurposed drugs, SARS-CoV-2specific antivirals should also be developed for the long-term benefit. Antivirals such as viral polymerase inhibitors and protease inhibitors should be prioritized due to their direct impact on viral replication. This is supported by previous experience with HCV, for which the development of direct acting antivirals (DAAs) substantially improved the therapeutic efficacy (over 95\% sustained virological responses) (155). Likewise, the introduction and advancement of combination antiretroviral therapy also successfully improved the survival of HIV-infected patients (156). Hence, development of specific antivirals with different targets in the SARS-CoV-2 life cycle and the use of a combination therapy could be more potent in reducing viral load and prevent severe disease progression.

\section{AUTHOR CONTRIBUTIONS}

Conceptualization: C-HLiu, C-HLu, and L-TL. WritingOriginal Draft: C-HLiu and C-HLu. Writing-Review and Editing: C-HLiu, SHW, and L-TL. Supervision: L-TL. Funding Acquisition: L-TL. All authors contributed to the article and approved the submitted version.

\section{FUNDING}

C-HLiu has received $\mathrm{PhD}$ fellowship from the Canadian Network on Hepatitis C (CanHepC). CanHepC is funded by a joint initiative of the Canadian Institutes of Health Research (CIHR) (NHC-142832) and the Public Health Agency of Canada (PHAC). L-TL is funded by the Ministry of Science and Technology of Taiwan (MOST107-2320-B-038-034-MY3). The funders had no role in study design, data collection and analysis, decision to publish, or preparation of the manuscript.

5. Hu Z, Song C, Xu C, Jin G, Chen Y, Xu X, et al. Clinical characteristics of 24 asymptomatic infections with COVID-19 screened among close contacts in Nanjing, China. Sci China Life Sci (2020) 63(5):706-11. doi: 10.1007/s11427020-1661-4

6. Arons MM, Hatfield KM, Reddy SC, Kimball A, James A, Jacobs JR, et al. Presymptomatic SARS-CoV-2 Infections and Transmission in a Skilled Nursing Facility. N Engl J Med (2020) 382(22):2081-90. doi: 10.1056/NEJMoa2008457

7. Hoffmann M, Kleine-Weber H, Schroeder S, Kruger N, Herrler T, Erichsen $\mathrm{S}$, et al. SARS-CoV-2 Cell Entry Depends on ACE2 and TMPRSS2 and Is Blocked by a Clinically Proven Protease Inhibitor. Cell (2020) 181(2):27180.e8. doi: 10.1016/j.cell.2020.02.052

8. De Wilde AH, Snijder EJ, Kikkert M, Van Hemert MJ. Host Factors in Coronavirus Replication. Curr Top Microbiol Immunol (2018) 419:1-42. doi: 10.1007/82_2017_25 
9. Wang K, Chen W, Zhang Z, Deng Y, Lian J-Q, Du P, et al. CD147-spike protein is a novel route for SARS-CoV-2 infection to host cells. Signal Transduct Targeted Ther (2020) 5(1):283. doi: 10.1038/s41392-020-00426-x

10. Daly JL, Simonetti B, Klein K, Chen K-E, Williamson MK, Antón-Plágaro C, et al. Neuropilin-1 is a host factor for SARS-CoV-2 infection. Science (2020) 370(6518):861-5. doi: 10.1126/science.abd3072

11. Cantuti-Castelvetri L, Ojha R, Pedro LD, Djannatian M, Franz J, Kuivanen S, et al. Neuropilin-1 facilitates SARS-CoV-2 cell entry and infectivity. Science (2020) 370(6518):856-60. doi: 10.1126/science.abd2985

12. Wang M, Cao R, Zhang L, Yang X, Liu J, Xu M, et al. Remdesivir and chloroquine effectively inhibit the recently emerged novel coronavirus (2019-nCoV) in vitro. Cell Res (2020) 30(3):269-71. doi: 10.1038/s41422020-0282-0

13. Hung IF, Lung KC, Tso EY, Liu R, Chung TW, Chu MY, et al. Triple combination of interferon beta-1b, lopinavir-ritonavir, and ribavirin in the treatment of patients admitted to hospital with COVID-19: an open-label, randomised, phase 2 trial. Lancet (2020) 395(10238):1695-1704. doi: 10.1016/S0140-6736(20)31042-4

14. Kaptein SJF, Jacobs S, Langendries L, Seldeslachts L, Ter Horst S, Liesenborghs L, et al. Antiviral treatment of SARS-CoV-2-infected hamsters reveals a weak effect of favipiravir and a complete lack of effect for hydroxychloroquine. (2020). doi: 10.1101/2020.06.19.159053

15. Cai Q, Yang M, Liu D, Chen J, Shu D, Xia J, et al. Experimental Treatment with Favipiravir for COVID-19: An Open-Label Control Study. Eng (Beijing) (2020) 34(10):1192-8. doi: 10.1016/j.eng.2020.03.007

16. Chen C, Huang J, Cheng Z, Wu J, Chen S, Zhang Y, et al. Favipiravir versus Arbidol for COVID-19: A Randomized Clinical Trial. (2020). doi: 10.1101/ 2020.03.17.20037432

17. Joshi S, Parkar J, Ansari A, Vora A, Talwar D, Tiwaskar M, et al. Role of favipiravir in the treatment of COVID-19. Int J Infect Dis (2021) 102:501-8. doi: 10.1016/j.ijid.2020.10.069

18. Beigel JH, Tomashek KM, Dodd LE, Mehta AK, Zingman BS, Kalil AC, et al. Remdesivir for the Treatment of Covid-19 - Preliminary Report. $N$ Engl J Med (2020) 383(19):1813-26. doi: 10.1056/NEJMoa2007764

19. Wang Y, Zhang D, Du G, Du R, Zhao J, Jin Y, et al. Remdesivir in adults with severe COVID-19: a randomised, double-blind, placebo-controlled, multicentre trial. Lancet (2020) 395(10236):1569-78. doi: 10.1016/s01406736(20)31022-9

20. Williamson BN, Feldmann F, Schwarz B, Meade-White K, Porter DP, Schulz J, et al. Clinical benefit of remdesivir in rhesus macaques infected with SARSCoV-2. Nature (2020) 585(7824):273-6. doi: 10.1038/s41586-020-2423-5

21. U.S. Food and Drug Administration. FDA Approves First Treatment for COVID-19 (2020). Available at: https://www.fda.gov/news-events/pressannouncements/fda-approves-first-treatment-covid-19 (Accessed 15 December 2020).

22. Sadeghi A, Asgari AA, Norouzi A, Kheiri Z, Anushirvani A, Montazeri M, et al. Sofosbuvir and Daclatasvir for the treatment of COVID-19: Results from a randomised controlled trial. In: . IAS COIVD-19 Conference (2020). Available at: https://aids2020.org/wp-content/uploads/2020/07/COVID-19press-conference-abstracts.pdf.

23. Sacramento CQ, Fintelman-Rodrigues N, Temerozo JR, Da Silva Gomes Dias S, Ferreira AC, Mattos M, et al. The in vitro antiviral activity of the antihepatitis $\mathrm{C}$ virus (HCV) drugs daclatasvir and sofosbuvir against SARSCoV-2. (2020). doi: 10.1101/2020.06.15.153411

24. Ma C, Sacco MD, Hurst B, Townsend JA, Hu Y, Szeto T, et al. Boceprevir, GC-376, and calpain inhibitors II, XII inhibit SARS-CoV-2 viral replication by targeting the viral main protease. Cell Res (2020) 30(8):678-92. doi: $10.1038 / \mathrm{s} 41422-020-0356-\mathrm{Z}$

25. Zhang L, Lin D, Sun X, Curth U, Drosten C, Sauerhering L, et al. Crystal structure of SARS-CoV-2 main protease provides a basis for design of improved alpha-ketoamide inhibitors. Science (2020) 368(6489):409-12. doi: 10.1126/science.abb3405

26. Dai W, Zhang B, Jiang XM, Su H, Li J, Zhao Y, et al. Structure-based design of antiviral drug candidates targeting the SARS-CoV-2 main protease. Science (2020) 368(6497):1331-5. doi: 10.1126/science.abb4489

27. Cao B, Wang Y, Wen D, Liu W, Wang J, Fan G, et al. A Trial of LopinavirRitonavir in Adults Hospitalized with Severe Covid-19. N Engl J Med (2020) 382(19):1787-99. doi: 10.1056/NEJMoa2001282
28. The Recovery Trial. Statement from the Chief Investigators of the Randomised Evaluation of COVid-19 thERapY (RECOVERY) Trial on lopinavir-ritonavir. (2020). Available at: https://www.recoverytrial.net/files/lopinavir-ritonavirrecovery-statement-29062020_final.pdf. (Accessed 01 July 2020).

29. Choy KT, Wong AY, Kaewpreedee P, Sia SF, Chen D, Hui KPY, et al. Remdesivir, lopinavir, emetine, and homoharringtonine inhibit SARS-CoV2 replication in vitro. Antiviral Res (2020) 178:104786. doi: 10.1016/ j.antiviral.2020.104786

30. Park S-J, Yu K-M, Kim Y-I, Kim S-M, Kim E-H, Kim S-G, et al. Antiviral Efficacies of FDA-Approved Drugs against SARS-CoV-2 Infection in Ferrets. mBio (2020) 11(3):e01114-20. doi: 10.1128/mBio.01114-20

31. Chen J, Xia L, Liu L, Xu Q, Ling Y, Huang D, et al. Antiviral Activity and Safety of Darunavir/Cobicistat for the Treatment of COVID-19. Open Forum Infect Dis (2020) 7(7):ofaa241. doi: 10.1093/ofid/ofaa241

32. De Meyer S, Bojkova D, Cinatl J, Van Damme E, Buyck C, Van Loock M, et al. Lack of antiviral activity of darunavir against SARS-CoV-2. Int J Infect Dis (2020) 97:7-10. doi: 10.1016/j.ijid.2020.05.085

33. Mantlo E, Bukreyeva N, Maruyama J, Paessler S, Huang C. Antiviral activities of type I interferons to SARS-CoV-2 infection. Antiviral Res (2020) 179:104811. doi: 10.1016/j.antiviral.2020.104811

34. Zhou Q, Chen V, Shannon CP, Wei XS, Xiang X, Wang X, et al. Interferonalpha2b Treatment for COVID-19. Front Immunol (2020) 11:1061. doi: $10.3389 /$ fimmu.2020.01061

35. Clementi N, Ferrarese R, Criscuolo E, Diotti RA, Castelli M, Scagnolari C, et al. Interferon-beta-1a Inhibition of Severe Acute Respiratory SyndromeCoronavirus 2 In Vitro When Administered After Virus Infection. J Infect Dis (2020) 222(5):722-5. doi: 10.1093/infdis/jiaa350

36. Davoudi-Monfared E, Rahmani H, Khalili H, Hajiabdolbaghi M, Salehi M, Abbasian L, et al. A Randomized Clinical Trial of the Efficacy and Safety of Interferon beta-1a in Treatment of Severe COVID-19. Antimicrob Agents Chemother (2020) 64(9):e01061-20. doi: 10.1128/AAC.01061-20

37. Stanifer ML, Kee C, Cortese M, Zumaran CM, Triana S, Mukenhirn M, et al. Critical Role of Type III Interferon in Controlling SARS-CoV-2 Infection in Human Intestinal Epithelial Cells. Cell Rep (2020) 32(1):107863. doi: 10.1016/j.celrep.2020.107863

38. Fu W, Liu Y, Xia L, Li M, Song Z, Hu H, et al. A clinical pilot study on the safety and efficacy of aerosol inhalation treatment of IFN- $\kappa$ plus TFF2 in patients with moderate COVID-19. EClinicalMedicine (2020) 25:100478. doi: 10.1016/j.eclinm.2020.100478

39. Hoffmann M, Schroeder S, Kleine-Weber H, Müller MA, Drosten C, Pöhlmann S. Nafamostat Mesylate Blocks Activation of SARS-CoV-2: New Treatment Option for COVID-19. Antimicrobial Agents Chemother (2020) 64(6):e00754-20. doi: 10.1128/aac.00754-20

40. Recovery Collaborative Group, Horby P, Lim WS, Emberson JR, Mafham M, Bell JL, et al. Dexamethasone in Hospitalized Patients with Covid-19 Preliminary Report. New Engl J Med (2020) NEJMoa2021436. doi: 10.1056/ NEJMoa2021436

41. The Recovery Trial. Statement from the Chief Investigators of the Randomised Evaluation of COVid-19 thERapY (RECOVERY) Trial on hydroxychloroquine. (2020). Available at: https://www.recoverytrial.net/ files/hcq-recovery-statement-050620-final-002.pdf (Accessed 01 July 2020).

42. Tang W, Cao Z, Han M, Wang Z, Chen J, Sun W, et al. Hydroxychloroquine in patients with mainly mild to moderate coronavirus disease 2019: open label, randomised controlled trial. Bmj (2020) 369:m1849. doi: 10.1136/ bmj.m1849

43. Hoffmann M, Mösbauer K, Hofmann-Winkler H, Kaul A, Kleine-Weber H, Krüger N, et al. Chloroquine does not inhibit infection of human lung cells with SARS-CoV-2. Nature (2020) 585(7826):588-90. doi: 10.1038/s41586020-2575-3

44. Liu J, Cao R, Xu M, Wang X, Zhang H, Hu H, et al. Hydroxychloroquine, a less toxic derivative of chloroquine, is effective in inhibiting SARS-CoV-2 infection in vitro. Cell Discovery (2020) 6:16. doi: 10.1038/s41421-020-0156-0

45. Rosenke K, Jarvis MA, Feldmann F, Schwarz B, Okumura A, Lovaglio J, et al. Hydroxychloroquine prophylaxis and treatment is ineffective in macaque and hamster SARS-CoV-2 disease models. JCI Insight (2020) 5(23):e143174. doi: $10.1172 /$ jci.insight. 143174

46. Yao X, Ye F, Zhang M, Cui C, Huang B, Niu P, et al. In Vitro Antiviral Activity and Projection of Optimized Dosing Design of Hydroxychloroquine for the 
Treatment of Severe Acute Respiratory Syndrome Coronavirus 2 (SARS-CoV2). Clin Infect Dis (2020) 71(15):732-9. doi: 10.1093/cid/ciaa237

47. Maisonnasse P, Guedj J, Contreras V, Behillil S, Solas C, Marlin R, et al. Hydroxychloroquine use against SARS-CoV-2 infection in non-human primates. Nature (2020) 585(7826):584-7. doi: 10.1038/s41586-020-2558-4

48. Li Y, Xie Z, Lin W, Cai W, Wen C, Guan Y, et al. Efficacy and safety of lopinavir/ritonavir or arbidol in adult patients with mild/moderate COVID19: an exploratory randomized controlled trial. Med (2020) 1(1):105-13.e4. doi: 10.1016/j.medj.2020.04.001

49. Wang X, Cao R, Zhang H, Liu J, Xu M, Hu H, et al. The anti-influenza virus drug, arbidol is an efficient inhibitor of SARS-CoV-2 in vitro. Cell Discov (2020) 6:28 doi: 10.1038/s41421-020-0169-8

50. World Health Organization. WHO discontinues hydroxychloroquine and lopinavir/ritonavir treatment arms for COVID-19. (2020). Available at: https://www.who.int/news-room/detail/04-07-2020-who-discontinueshydroxychloroquine-and-lopinavir-ritonavir-treatment-arms-for-covid-19 (Accessed 03 September 2020).

51. Nyström K, Waldenström J, Tang KW, Lagging M. Ribavirin: pharmacology, multiple modes of action and possible future perspectives. Future Virol (2019) 14(3):153-60. doi: 10.2217/fvl-2018-0166

52. Tan EL, Ooi EE, Lin CY, Tan HC, Ling AE, Lim B, et al. Inhibition of SARS coronavirus infection in vitro with clinically approved antiviral drugs. Emerg Infect Dis (2004) 10(4):581-6. doi: 10.3201/eid1004.030458

53. Cinatl J, Morgenstern B, Bauer G, Chandra P, Rabenau H, Doerr HW. Glycyrrhizin, an active component of liquorice roots, and replication of SARS-associated coronavirus. Lancet (2003) 361(9374):2045-6. doi: 10.1016/s0140-6736(03)13615-x

54. Morgenstern B, Michaelis M, Baer PC, Doerr HW, Cinatl JJr. Ribavirin and interferon-beta synergistically inhibit SARS-associated coronavirus replication in animal and human cell lines. Biochem Biophys Res Commun (2005) 326(4):905-8. doi: 10.1016/j.bbrc.2004.11.128

55. Stockman LJ, Bellamy R, Garner P. SARS: systematic review of treatment effects. PloS Med (2006) 3(9):e343. doi: 10.1371/journal.pmed.0030343

56. Barnard DL, Day CW, Bailey K, Heiner M, Montgomery R, Lauridsen L, et al. Enhancement of the infectivity of SARS-CoV in BALB/c mice by IMP dehydrogenase inhibitors, including ribavirin. Antiviral Res (2006) 71(1):5363. doi: 10.1016/j.antiviral.2006.03.001

57. Day CW, Baric R, Cai SX, Frieman M, Kumaki Y, Morrey JD, et al. A new mouse-adapted strain of SARS-CoV as a lethal model for evaluating antiviral agents in vitro and in vivo. Virology (2009) 395(2):210-22. doi: 10.1016/ j.virol.2009.09.023

58. Hart BJ, Dyall J, Postnikova E, Zhou H, Kindrachuk J, Johnson RF, et al. Interferon-beta and mycophenolic acid are potent inhibitors of Middle East respiratory syndrome coronavirus in cell-based assays. J Gen Virol (2014) 95 (Pt 3):571-7. doi: 10.1099/vir.0.061911-0

59. Mchutchison JG, Gordon SC, Schiff ER, Shiffman ML, Lee WM, Rustgi VK, et al. Interferon alfa- $2 \mathrm{~b}$ alone or in combination with ribavirin as initial treatment for chronic hepatitis C. Hepatitis Interventional Therapy Group. N Engl J Med (1998) 339(21):1485-92. doi: 10.1056/NEJM199811193392101

60. Chu CM, Cheng VC, Hung IF, Wong MM, Chan KH, Chan KS, et al. Role of lopinavir/ritonavir in the treatment of SARS: initial virological and clinical findings. Thorax (2004) 59(3):252-6. doi: 10.1136/thorax.2003.012658

61. Kim UJ, Won EJ, Kee SJ, Jung SI, Jang HC. Combination therapy with lopinavir/ritonavir, ribavirin and interferon-alpha for Middle East respiratory syndrome. Antivir Ther (2016) 21(5):455-9. doi: 10.3851/IMP3002

62. Furuta Y, Takahashi K, Kuno-Maekawa M, Sangawa H, Uehara S, Kozaki K, et al. Mechanism of action of T-705 against influenza virus. Antimicrob Agents Chemother (2005) 49(3):981-6. doi: 10.1128/AAC.49.3.981-986.2005

63. Sangawa H, Komeno T, Nishikawa H, Yoshida A, Takahashi K, Nomura N, et al. Mechanism of action of T-705 ribosyl triphosphate against influenza virus RNA polymerase. Antimicrob Agents Chemother (2013) 57(11):5202-8. doi: 10.1128/AAC.00649-13

64. Furuta Y, Takahashi K, Fukuda Y, Kuno M, Kamiyama T, Kozaki K, et al. In vitro and in vivo activities of anti-influenza virus compound T-705. Antimicrob Agents Chemother (2002) 46(4):977-81. doi: 10.1128/ aac.46.4.977-981.2002

65. Sidwell RW, Barnard DL, Day CW, Smee DF, Bailey KW, Wong MH, et al. Efficacy of orally administered T-705 on lethal avian influenza A (H5N1) virus infections in mice. Antimicrob Agents Chemother (2007) 51(3):845-51. doi: 10.1128/AAC.01051-06

66. Sleeman K, Mishin VP, Deyde VM, Furuta Y, Klimov AI, Gubareva LV. In vitro antiviral activity of favipiravir (T-705) against drug-resistant influenza and 2009 A(H1N1) viruses. Antimicrob Agents Chemother (2010) 54 (6):2517-24. doi: 10.1128/AAC.01739-09

67. Watanabe T, Kiso M, Fukuyama S, Nakajima N, Imai M, Yamada S, et al. Characterization of H7N9 influenza A viruses isolated from humans. Nature (2013) 501(7468):551-5. doi: 10.1038/nature12392

68. Furuta Y, Komeno T, Nakamura T. Favipiravir (T-705), a broad spectrum inhibitor of viral RNA polymerase. Proc Jpn Acad Ser B Phys Biol Sci (2017) 93(7):449-63. doi: 10.2183/pjab.93.027

69. Warren TK, Jordan R, Lo MK, Ray AS, Mackman RL, Soloveva V, et al. Therapeutic efficacy of the small molecule GS-5734 against Ebola virus in rhesus monkeys. Nature (2016) 531(7594):381-5. doi: 10.1038/nature17180

70. Jordan PC, Liu C, Raynaud P, Lo MK, Spiropoulou CF, Symons JA, et al. Initiation, extension, and termination of RNA synthesis by a paramyxovirus polymerase. PloS Pathog (2018) 14(2):e1006889. doi: 10.1371/ journal.ppat.1006889

71. Tchesnokov EP, Feng JY, Porter DP, Gotte M. Mechanism of Inhibition of Ebola Virus RNA-Dependent RNA Polymerase by Remdesivir. Viruses (2019) 11(4):306. doi: 10.3390/v11040326

72. Gordon CJ, Tchesnokov EP, Feng JY, Porter DP, Gotte M. The antiviral compound remdesivir potently inhibits RNA-dependent RNA polymerase from Middle East respiratory syndrome coronavirus. J Biol Chem (2020) 295 (15):4773-9. doi: 10.1074/jbc.AC120.013056

73. Lo MK, Jordan R, Arvey A, Sudhamsu J, Shrivastava-Ranjan P, Hotard AL, et al. GS-5734 and its parent nucleoside analog inhibit Filo-, Pneumo-, and Paramyxoviruses. Sci Rep (2017) 7:43395. doi: 10.1038/srep43395

74. Sheahan TP, Sims AC, Graham RL, Menachery VD, Gralinski LE, Case JB, et al. Broad-spectrum antiviral GS-5734 inhibits both epidemic and zoonotic coronaviruses. Sci Transl Med (2017) 9(396):eaal3653. doi: 10.1126/ scitranslmed.aal3653

75. Agostini ML, Andres EL, Sims AC, Graham RL, Sheahan TP, Lu X, et al. Coronavirus Susceptibility to the Antiviral Remdesivir (GS-5734) Is Mediated by the Viral Polymerase and the Proofreading Exoribonuclease. mBio (2018) 9(2):e00221-18. doi: 10.1128/mBio.00221-18

76. Brown AJ, Won JJ, Graham RL, Dinnon KH,3, Sims AC, Feng JY, et al. Broad spectrum antiviral remdesivir inhibits human endemic and zoonotic deltacoronaviruses with a highly divergent RNA dependent RNA polymerase. Antiviral Res (2019) 169:104541. doi: 10.1016/j.antiviral.2019.104541

77. Mulangu S, Dodd LE, Davey RTJr., Tshiani Mbaya O, Proschan M, Mukadi D, et al. A Randomized, Controlled Trial of Ebola Virus Disease Therapeutics. N Engl J Med (2019) 381(24):2293-303. doi: 10.1056/NEJMoa1910993

78. Sheahan TP, Sims AC, Leist SR, Schafer A, Won J, Brown AJ, et al. Comparative therapeutic efficacy of remdesivir and combination lopinavir, ritonavir, and interferon beta against MERS-CoV. Nat Commun (2020) 11 (1):222. doi: 10.1038/s41467-019-13940-6

79. De Wit E, Feldmann F, Cronin J, Jordan R, Okumura A, Thomas T, et al. Prophylactic and therapeutic remdesivir (GS-5734) treatment in the rhesus macaque model of MERS-CoV infection. Proc Natl Acad Sci USA (2020) 117(12):6771-6. doi: 10.1073/pnas.1922083117

80. U.S. Food and Drug Administration. Coronavirus (COVID-19) Update: FDA Issues Emergency Use Authorization for Potential COVID-19 Treatment (2020). Available at: https://www.fda.gov/news-events/pressannouncements/coronavirus-covid-19-update-fda-issues-emergency-useauthorization-potential-covid-19-treatment (Accessed 01 July 2020).

81. Gilead Sciences I. Gilead Announces Approval of Veklury ${ }^{\circledR}$ (remdesivir) in Japan for Patients With Severe COVID-19. (2020). Available at: https://www. gilead.com/news-and-press/press-room/press-releases/2020/5/gileadannounces-approval-of-veklury-remdesivir-in-japan-for-patients-withsevere-covid19 (Accessed 01 July 2020).

82. Goldman JD, Lye DCB, Hui DS, Marks KM, Bruno R, Montejano R, et al. Remdesivir for 5 or 10 Days in Patients with Severe Covid-19. N Engl J Med (2020) 383(19):1827-37. doi: 10.1056/NEJMoa2015301

83. Yan VC, Muller FL. Advantages of the Parent Nucleoside GS-441524 over Remdesivir for Covid-19 Treatment. ACS Med Chem Lett (2020) 11 (7):1361-6. doi: 10.1021/acsmedchemlett.0c00316 
84. Bhatia HK, Singh H, Grewal N, Natt NK. Sofosbuvir: A novel treatment option for chronic hepatitis C infection. J Pharmacol Pharmacother (2014) 5 (4):278-84. doi: 10.4103/0976-500X.142464

85. Sulkowski MS, Gardiner DF, Rodriguez-Torres M, Reddy KR, Hassanein T, Jacobson I, et al. Daclatasvir plus sofosbuvir for previously treated or untreated chronic HCV infection. N Engl J Med (2014) 370(3):211-21. doi: 10.1056/NEJMoa1306218

86. Gao M, Nettles RE, Belema M, Snyder LB, Nguyen VN, Fridell RA, et al. Chemical genetics strategy identifies an HCV NS5A inhibitor with a potent clinical effect. Nature (2010) 465(7294):96-100. doi: 10.1038/ nature 08960

87. Jacome R, Campillo-Balderas JA, Ponce De Leon S, Becerra A, Lazcano A. Sofosbuvir as a potential alternative to treat the SARS-CoV-2 epidemic. Sci Rep (2020) 10(1):9294. doi: 10.1038/s41598-020-66440-9

88. Elfiky AA. Anti-HCV, nucleotide inhibitors, repurposing against COVID19. Life Sci (2020) 248:117477. doi: 10.1016/j.lfs.2020.117477

89. Sayad B, Sobhani M, Khodarahmi R. Sofosbuvir as Repurposed Antiviral Drug Against COVID-19: Why Were We Convinced to Evaluate the Drug in a Registered/Approved Clinical Trial? Arch Med Res (2020) 51(6):577-81. doi: 10.1016/j.arcmed.2020.04.018

90. Bafna K, Krug RM, Montelione GT. Structural Similarity of SARS-CoV2 M (pro) and HCV NS3/4A Proteases Suggests New Approaches for Identifying Existing Drugs Useful as COVID-19 Therapeutics. (2020). doi: 10.26434/ chemrxiv. 12153615

91. Elfiky A, Ibrahim NS. Anti-SARS and anti-HCV drugs repurposing against the Papain-like protease of the newly emerged coronavirus (2019-nCoV). (2020). doi: 10.21203/rs.2.23280/v1

92. Zhang L, Lin D, Kusov Y, Nian Y, Ma Q, Wang J, et al. alpha-Ketoamides as Broad-Spectrum Inhibitors of Coronavirus and Enterovirus Replication: Structure-Based Design, Synthesis, and Activity Assessment. J Med Chem (2020) 63(9):4562-78. doi: 10.1021/acs.jmedchem.9b01828

93. Kim Y, Lovell S, Tiew KC, Mandadapu SR, Alliston KR, Battaile KP, et al. Broad-spectrum antivirals against $3 \mathrm{C}$ or $3 \mathrm{C}$-like proteases of picornaviruses, noroviruses, and coronaviruses. J Virol (2012) 86(21):11754-62. doi: 10.1128/JVI.01348-12

94. Kim Y, Liu H, Galasiti Kankanamalage AC, Weerasekara S, Hua DH, Groutas WC, et al. Reversal of the Progression of Fatal Coronavirus Infection in Cats by a Broad-Spectrum Coronavirus Protease Inhibitor. PloS Pathog (2016) 12(3):e1005531. doi: 10.1371/journal.ppat.1005531

95. Pedersen NC, Kim Y, Liu H, Galasiti Kankanamalage AC, Eckstrand C, Groutas WC, et al. Efficacy of a 3C-like protease inhibitor in treating various forms of acquired feline infectious peritonitis. J Feline Med Surg (2018) 20 (4):378-92. doi: 10.1177/1098612X17729626

96. Petushkova AI, Zamyatnin AA. Papain-Like Proteases as Coronaviral Drug Targets: Current Inhibitors, Opportunities, and Limitations. Pharmaceuticals (2020) 13(10):277. doi: 10.3390/ph13100277

97. Habtemariam S, Nabavi SF, Banach M, Berindan-Neagoe I, Sarkar K, Sil PC, et al. Should We Try SARS-CoV-2 Helicase Inhibitors for COVID-19 Therapy? Arch Med Res (2020) 51(7):733-5. doi: 10.1016/j.arcmed.2020.05.024

98. Tanner JA, Zheng BJ, Zhou J, Watt RM, Jiang JQ, Wong KL, et al. The adamantane-derived bananins are potent inhibitors of the helicase activities and replication of SARS coronavirus. Chem Biol (2005) 12(3):303-11. doi: 10.1016/j.chembiol.2005.01.006

99. Adedeji AO, Singh K, Calcaterra NE, Dediego ML, Enjuanes L, Weiss S, et al. Severe acute respiratory syndrome coronavirus replication inhibitor that interferes with the nucleic acid unwinding of the viral helicase. Antimicrob Agents Chemother (2012) 56(9):4718-28. doi: 10.1128/AAC.00957-12

100. Adedeji AO, Singh K, Kassim A, Coleman CM, Elliott R, Weiss SR, et al. Evaluation of SSYA10-001 as a replication inhibitor of severe acute respiratory syndrome, mouse hepatitis, and Middle East respiratory syndrome coronaviruses. Antimicrob Agents Chemother (2014) 58 (8):4894-8. doi: 10.1128/AAC.02994-14

101. Walmsley S, Christian MD. The role of lopinavir/ritonavir (Kaletra) in the management of HIV infected adults. Expert Rev Anti Infect Ther (2003) 1 (3):389-401. doi: 10.1586/14787210.1.3.389

102. Cvetkovic RS, Goa KL. Lopinavir/ritonavir: a review of its use in the management of HIV infection. Drugs (2003) 63(8):769-802. doi: 10.2165/ 00003495-200363080-00004
103. Kaplan SS, Hicks CB. Lopinavir/ritonavir in the treatment of human immunodeficiency virus infection. Expert Opin Pharmacother (2005) 6 (9):1573-85. doi: 10.1517/14656566.6.9.1573

104. Chan KS, Lai ST, Chu CM, Tsui E, Tam CY, Wong MM, et al. Treatment of severe acute respiratory syndrome with lopinavir/ritonavir: a multicentre retrospective matched cohort study. Hong Kong Med J (2003) 9(6):399-406.

105. Nukoolkarn V, Lee VS, Malaisree M, Aruksakulwong O, Hannongbua S. Molecular dynamic simulations analysis of ritonavir and lopinavir as SARSCoV 3CL(pro) inhibitors. J Theor Biol (2008) 254(4):861-7. doi: 10.1016/ j.jtbi.2008.07.030

106. Chan JF, Yao Y, Yeung ML, Deng W, Bao L, Jia L, et al. Treatment With Lopinavir/Ritonavir or Interferon-betalb Improves Outcome of MERS-CoV Infection in a Nonhuman Primate Model of Common Marmoset. J Infect Dis (2015) 212(12):1904-13. doi: 10.1093/infdis/jiv392

107. Arabi YM, Alothman A, Balkhy HH, Al-Dawood A, Aljohani S, Al Harbi S, et al. Treatment of Middle East Respiratory Syndrome with a combination of lopinavir-ritonavir and interferon-betalb (MIRACLE trial): study protocol for a randomized controlled trial. Trials (2018) 19(1):81. doi: 10.1186/ s13063-017-2427-0

108. Cao B, Zhang D, Wang C. A Trial of Lopinavir-Ritonavir in Covid-19. Reply. N Engl J Med (2020) 382(21):e68. doi: 10.1056/NEJMc2008043

109. Carmona-Bayonas A, Jimenez-Fonseca P, Castanon E. A Trial of LopinavirRitonavir in Covid-19. N Engl J Med (2020) 382(21):e68. doi: 10.1056/ NEJMc2008043

110. Corrao S, Natoli G, Cacopardo B. A Trial of Lopinavir-Ritonavir in Covid19. N Engl J Med (2020) 382(21):e68. doi: 10.1056/NEJMc2008043

111. Dalerba P, Levin B, Thompson JL. A Trial of Lopinavir-Ritonavir in Covid19. N Engl J Med (2020) 382(21):e68. doi: 10.1056/NEJMc2008043

112. Havlichek D Jr. A Trial of Lopinavir-Ritonavir in Covid-19. N Engl J Med (2020) 382(21):e68. doi: 10.1056/NEJMc2008043

113. Kunz KM. A Trial of Lopinavir-Ritonavir in Covid-19. N Engl J Med (2020) 382(21):e68. doi: 10.1056/NEJMc2008043

114. Lascar RM, Benn P. Role of darunavir in the management of HIV infection. HIV AIDS (Auckl) (2009) 1:31-39. doi: 10.2147/hiv.s5397

115. Mckeage K, Perry CM, Keam SJ. Darunavir: a review of its use in the management of HIV infection in adults. Drugs (2009) 69(4):477-503. doi: 10.2165/00003495-200969040-00007

116. Koh Y, Matsumi S, Das D, Amano M, Davis DA, Li J, et al. Potent inhibition of HIV-1 replication by novel non-peptidyl small molecule inhibitors of protease dimerization. J Biol Chem (2007) 282(39):28709-20. doi: 10.1074/ jbc.M703938200

117. U.S. Food and Drug Administration. Prezcobix (darunavir and cobicistat) Tablet (2016). Available at: https://www.accessdata.fda.gov/drugsatfda_docs/ nda/2015/205395Orig1s000TOC.cfm (Accessed 16 July 2020).

118. European Medicines Agency. Rezolsta (darunavir / cobicistat) (2014). Available at: https://www.ema.europa.eu/en/medicines/human/EPAR/ rezolsta (Accessed 16 July 2020).

119. Cinatl J, Morgenstern B, Bauer G, Chandra P, Rabenau H, Doerr HW. Treatment of SARS with human interferons. Lancet (2003) 362(9380):293-4. doi: 10.1016/s0140-6736(03)13973-6

120. Barnard DL, Day CW, Bailey K, Heiner M, Montgomery R, Lauridsen L, et al. Evaluation of immunomodulators, interferons and known in vitro SARS-coV inhibitors for inhibition of SARS-coV replication in BALB/c mice. Antivir Chem Chemother (2006) 17(5):275-84. doi: 10.1177/ 095632020601700505

121. Channappanavar R, Fehr AR, Vijay R, Mack M, Zhao J, Meyerholz DK, et al. Dysregulated Type I Interferon and Inflammatory Monocyte-Macrophage Responses Cause Lethal Pneumonia in SARS-CoV-Infected Mice. Cell Host Microbe (2016) 19(2):181-93. doi: 10.1016/j.chom.2016.01.007

122. Loutfy MR, Blatt LM, Siminovitch KA, Ward S, Wolff B, Lho H, et al. Interferon alfacon-1 plus corticosteroids in severe acute respiratory syndrome: a preliminary study. JAMA (2003) 290(24):3222-8. doi: 10.1001/jama.290.24.3222

123. Chan JF, Chan KH, Kao RY, To KK, Zheng BJ, Li CP, et al. Broad-spectrum antivirals for the emerging Middle East respiratory syndrome coronavirus. J Infect (2013) 67(6):606-16. doi: 10.1016/j.jinf.2013.09.029

124. Jeon YJ, Gil CH, Jo A, Won J, Kim S, Kim HJ. The influence of interferonlambda on restricting Middle East Respiratory Syndrome Coronavirus 
replication in the respiratory epithelium. Antiviral Res (2020) 180:104860. doi: 10.1016/j.antiviral.2020.104860

125. Falzarano D, De Wit E, Rasmussen AL, Feldmann F, Okumura A, Scott DP, et al. Treatment with interferon-alpha2b and ribavirin improves outcome in MERS-CoV-infected rhesus macaques. Nat Med (2013) 19(10):1313-7. doi: $10.1038 / \mathrm{nm} .3362$

126. Arabi YM, Shalhoub S, Mandourah Y, Al-Hameed F, Al-Omari A, Al Qasim E, et al. Ribavirin and Interferon Therapy for Critically Ill Patients With Middle East Respiratory Syndrome: A Multicenter Observational Study. Clin Infect Dis (2020) 70(9):1837-44. doi: 10.1093/cid/ciz544

127. Jalkanen J, Hollmen M, Jalkanen S. Interferon beta-1a for COVID-19: critical importance of the administration route. Crit Care (2020) 24(1):335. doi: 10.1186/s13054-020-03048-5

128. Talukdar R, Saikia N, Singal DK, Tandon R. Chronic pancreatitis: evolving paradigms. Pancreatology (2006) 6(5):440-9. doi: 10.1159/000094561

129. Kawase M, Shirato K, Van Der Hoek L, Taguchi F, Matsuyama S. Simultaneous treatment of human bronchial epithelial cells with serine and cysteine protease inhibitors prevents severe acute respiratory syndrome coronavirus entry. J Virol (2012) 86(12):6537-45. doi: 10.1128/JVI.00094-12

130. Zhou Y, Vedantham P, Lu K, Agudelo J, Carrion RJr., Nunneley JW, et al. Protease inhibitors targeting coronavirus and filovirus entry. Antiviral Res (2015) 116:76-84. doi: 10.1016/j.antiviral.2015.01.011

131. U.S. Food and Drug Administration. Dexamethasone sodium phosphate (2014). Available at: https://www.accessdata.fda.gov/drugsatfda_docs/label/ 2014/040572s002lbl.pdf (Accessed 03 September 2020).

132. Shang L, Zhao J, Hu Y, Du R, Cao B. On the use of corticosteroids for 2019nCoV pneumonia. Lancet (2020) 395(10225):683-4. doi: 10.1016/s01406736(20)30361-5

133. Ye Z, Wang Y, Colunga-Lozano LE, Prasad M, Tangamornsuksan W, Rochwerg B, et al. Efficacy and safety of corticosteroids in COVID-19 based on evidence for COVID-19, other coronavirus infections, influenza, community-acquired pneumonia and acute respiratory distress syndrome: a systematic review and meta-analysis. Can Med Assoc J (2020) 192(27):E75667. doi: $10.1503 / \mathrm{cmaj} .200645$

134. Russell CD, Millar JE, Baillie JK. Clinical evidence does not support corticosteroid treatment for 2019-nCoV lung injury. Lancet (2020) 395 (10223):473-5. doi: 10.1016/s0140-6736(20)30317-2

135. National Institutes of Health. Corticosteroids | Coronavirus Disease COVID19 (2020). Available at: https://www.covid19treatmentguidelines.nih.gov/ immune-based-therapy/immunomodulators/corticosteroids/ (Accessed 03 September 2020).

136. Ishiyama Y, Gallagher PE, Averill DB, Tallant EA, Brosnihan KB, Ferrario CM. Upregulation of angiotensin-converting enzyme 2 after myocardial infarction by blockade of angiotensin II receptors. Hypertension (2004) 43 (5):970-6. doi: 10.1161/01.HYP.0000124667.34652.1a

137. Ferrario CM, Jessup J, Chappell MC, Averill DB, Brosnihan KB, Tallant EA, et al. Effect of angiotensin-converting enzyme inhibition and angiotensin II receptor blockers on cardiac angiotensin-converting enzyme 2. Circulation (2005) 111(20):2605-10. doi: 10.1161/CIRCULATIONAHA.104.510461

138. Imai Y, Kuba K, Rao S, Huan Y, Guo F, Guan B, et al. Angiotensinconverting enzyme 2 protects from severe acute lung failure. Nature (2005) 436(7047):112-6. doi: 10.1038/nature03712

139. Kuba K, Imai Y, Rao S, Gao H, Guo F, Guan B, et al. A crucial role of angiotensin converting enzyme 2 (ACE2) in SARS coronavirus-induced lung injury. Nat Med (2005) 11(8):875-9. doi: 10.1038/nm1267

140. Gurwitz D. Angiotensin receptor blockers as tentative SARS-CoV-2 therapeutics. Drug Dev Res (2020) 81(5):537-40. doi: 10.1002/ddr.21656

141. Tignanelli CJ, Ingraham NE, Sparks MA, Reilkoff R, Bezdicek T, Benson B, et al. Antihypertensive drugs and risk of COVID-19? Lancet Respir Med (2020) 8(5):e30-e31. doi: 10.1016/S2213-2600(20)30153-3

142. Messerli FH, Siontis GCM, Rexhaj E. COVID-19 and Renin Angiotensin Blockers: Current Evidence and Recommendations. Circulation (2020) 141 (25):2042-4. doi: 10.1161/CIRCULATIONAHA.120.047022
143. Savarino A, Boelaert JR, Cassone A, Majori G, Cauda R. Effects of chloroquine on viral infections: an old drug against today's diseases? Lancet Infect Dis (2003) 3(11):722-7. doi: 10.1016/s1473-3099(03)00806-5

144. Vincent MJ, Bergeron E, Benjannet S, Erickson BR, Rollin PE, Ksiazek TG, et al. Chloroquine is a potent inhibitor of SARS coronavirus infection and spread. Virol J (2005) 2:69. doi: 10.1186/1743-422X-2-69

145. Gao J, Tian Z, Yang X. Breakthrough: Chloroquine phosphate has shown apparent efficacy in treatment of COVID-19 associated pneumonia in clinical studies. Biosci Trends (2020) 14(1):72-3. doi: 10.5582/bst.2020.01047

146. Rosendaal FR. Review of: "Hydroxychloroquine and azithromycin as a treatment of COVID-19: results of an open-label non-randomized clinical trial Gautret et al 2010, DOI:10.1016/j.ijantimicag.2020.105949. Int J Antimicrobial Agents (2020) 56(1):106063. doi: 10.1016/j.ijantimicag. 2020.106063

147. U.S. Food and Drug Administration. Coronavirus (COVID-19) Update: FDA Revokes Emergency Use Authorization for Chloroquine and Hydroxychloroquine (2020). Available at: https://www.fda.gov/news-events/ press-announcements/coronavirus-covid-19-update-fda-revokesemergency-use-authorization-chloroquine-and (Accessed 10 December 2020).

148. Blaising J, Polyak SJ, Pecheur EI. Arbidol as a broad-spectrum antiviral: an update. Antiviral Res (2014) 107:84-94. doi: 10.1016/j.antiviral.2014. 04.006

149. Leneva IA, Russell RJ, Boriskin YS, Hay AJ. Characteristics of arbidolresistant mutants of influenza virus: implications for the mechanism of antiinfluenza action of arbidol. Antiviral Res (2009) 81(2):132-40. doi: 10.1016/ j.antiviral.2008.10.009

150. Khamitov RA, Loginova S, Shchukina VN, Borisevich SV, Maksimov VA, Shuster AM. [Antiviral activity of arbidol and its derivatives against the pathogen of severe acute respiratory syndrome in the cell cultures]. Vopr Virusol (2008) 53(4):9-13.

151. Zhu Z, Lu Z, Xu T, Chen C, Yang G, Zha T, et al. Arbidol Monotherapy is Superior to Lopinavir/ritonavir in Treating COVID-19. J Infect (2020) 81(1): e21-3. doi: 10.1016/j.jinf.2020.03.060

152. Wang Z, Yang B, Li Q, Wen L, Zhang R. Clinical Features of 69 Cases with Coronavirus Disease 2019 in Wuhan, China. Clin Infect Dis (2020) 71 (15):769-77. doi: 10.1093/cid/ciaa272

153. Deng L, Li C, Zeng Q, Liu X, Li X, Zhang H, et al. Arbidol combined with $\mathrm{LPV} / \mathrm{r}$ versus $\mathrm{LPV} / \mathrm{r}$ alone against Corona Virus Disease 2019: A retrospective cohort study. J Infect (2020) 81(1):e1-e5. doi: 10.1016/ j.jinf.2020.03.002

154. Funnell SGP, Dowling WE, Muñoz-Fontela C, Gsell PS, Ingber DE, Hamilton GA, et al. Emerging preclinical evidence does not support broad use of hydroxychloroquine in COVID-19 patients. Nat Commun (2020) 11 (1):4253. doi: 10.1038/s41467-020-17907-w

155. Holmes JA, Rutledge SM, Chung RT. Direct-acting antiviral treatment for hepatitis C. Lancet (2019) 393(10179):1392-4. doi: 10.1016/s0140-6736(18) 32326-2

156. Trickey A, May MT, Vehreschild J-J, Obel N, Gill MJ, Crane HM, et al. Survival of HIV-positive patients starting antiretroviral therapy between 1996 and 2013: a collaborative analysis of cohort studies. Lancet HIV (2017) 4(8):e349-56. doi: 10.1016/s2352-3018(17)30066-8

Conflict of Interest: The authors declare that the research was conducted in the absence of any commercial or financial relationships that could be construed as a potential conflict of interest.

Copyright (c) $2021 \mathrm{Liu}, \mathrm{Lu}$, Wong and Lin. This is an open-access article distributed under the terms of the Creative Commons Attribution License (CC BY). The use, distribution or reproduction in other forums is permitted, provided the original author(s) and the copyright owner(s) are credited and that the original publication in this journal is cited, in accordance with accepted academic practice. No use, distribution or reproduction is permitted which does not comply with these terms. 